\title{
Analysis of Trends and Emerging Technologies in Water Electrolysis Research Based on a Computational Method: A Comparison with Fuel Cell Research
}

\author{
Takaya Ogawa ${ }^{1, *,+}$, Mizutomo Takeuchi $^{2}$ and Yuya Kajikawa ${ }^{2}$ \\ 1 SUNCAT Center for Interface Science and Catalysis, Department of Chemical Engineering, Stanford \\ University, 443 Via Ortega, Stanford, CA 94305, USA \\ 2 Department of Technology and Innovation Management, School of Environment and Society, \\ Tokyo Institute of Technology, Tokyo 108-0023, Japan, takeuchi@mot.titech.ac.jp (M.T.); \\ kajikawa@mot.titech.ac.jp (Y.K.) \\ * Correspondence: takayao@stanford.edu or ogawa.takaya.8s@kyoto-u.ac.jp; Tel.: +81-3-3454-8754 \\ + Current address: Department of Socio-Environmental Energy Science, Graduate School of Energy Science, \\ Kyoto University, Yoshida-Honmachi, Sakyo-ku, Kyoto 606-8501, Japan.
}

Received: 31 December 2017; Accepted: 7 February 2018; Published: 11 February 2018

\begin{abstract}
Water electrolysis for hydrogen production has received increasing attention, especially for accumulating renewable energy. Here, we comprehensively reviewed all water electrolysis research areas through computational analysis, using a citation network to objectively detect emerging technologies and provide interdisciplinary data for forecasting trends. The results show that all research areas increase their publication counts per year, and the following two areas are particularly increasing in terms of number of publications: "microbial electrolysis" and "catalysts in an alkaline water electrolyzer (AWE) and in a polymer electrolyte membrane water electrolyzer (PEME).". Other research areas, such as AWE and PEME systems, solid oxide electrolysis, and the whole renewable energy system, have recently received several review papers, although papers that focus on specific technologies and are cited frequently have not been published within the citation network. This indicates that these areas receive attention, but there are no novel technologies that are the center of the citation network. Emerging technologies detected within these research areas are presented in this review. Furthermore, a comparison with fuel cell research is conducted because water electrolysis is the reverse reaction to fuel cells, and similar technologies are employed in both areas. Technologies that are not transferred between fuel cells and water electrolysis are introduced, and future water electrolysis trends are discussed.
\end{abstract}

Keywords: water electrolysis; alkaline water electrolyzer; polymer electrolyte membrane water electrolyzer; solid oxide electrolyzer; microbial electrolyzers; hydrogen production; bibliometrics; citation network

\section{Introduction}

Renewable energy (such as solar and wind power) has received increasing focus as it is unlimited and does not produce waste. However, renewable energy fluctuates temporally, and its energy density per land area is small [1,2]. A solution to this is to accumulate energy when surely surplus power is produced, and utilize it during shortfalls. The low energy density can be overcome by transporting renewable energy from a region with surplus power. Rechargeable batteries are not suitable for accumulating and transporting energy as the metals used in batteries are expensive, and the energy density per unit weight is low [3]. Water electrolysis is promising as electricity supplied from renewable energy can be stored as hydrogen, which has high energy density per unit weight (Figure 1a). Hydrogen storage is one of the best methods of accumulating and transporting renewable 
energy. Water electrolysis research has recently received great attention for the above reasons [4-6]. It is important for not only researchers but also governmental agencies to understand which topics are promising so that they can be further developed. Currently, over 12,000 academic papers have been published about water electrolysis, and over 1500 papers are published per year. It is difficult to read such a large amount manually. Research topics are divided into several categories that most would find difficult to understand, excluding the experts of each topic. It is also difficult for experts to understand whole research topics, and it is inevitable that their overview would be somewhat tailored to their own knowledge and interests. To objectively identify notable and well-developed areas of studies, a computational and objective analytical method is necessary.

Bibliometrics, which has recently advanced, can statistically and objectively analyze publications following a computational method [7-10]. For example, using citation network data, publications can automatically be classified into several clusters that cover a specific research topic [11-13]. The clusters contain information such as publication number, average publication year, and the distribution of affiliations that conducted research by country, which are useful for determining whether a topic in a cluster is emerging or not, and helps with evaluating the strength of a country in a particular research area [14]. In addition, keywords in abstracts can be utilized to determine similarities between patents and academic papers, which identifies gaps between commercialization and academic research [15], and the potential of academic research to be commercialized [16]. Moreover, information on the similarity between different research areas can allow researchers to come up with new research proposals [17]. This method can also analyze a collection of published data, such as academic papers about water electrolysis.

In this review, water electrolysis research is objectively and comprehensively analyzed by bibliometrics. Academic papers relating to water electrolysis were divided into several clusters that focus on specific research topics based on the citation network. The number of publications per year, total number of publications, and average number of publications per year of each cluster were determined, which were used to assess whether a topic in a cluster is emerging or mature. We analyzed the trends of whole water electrolysis research areas to fairly evaluate the importance of certain topics in each area.

Water electrolysis technologies are similar to those in fuel cell research, because the reaction in a fuel cell is the reverse of water electrolysis (Figure 1a,b). The number of published academic research papers about fuel cells was approximately 94,000 as of 2016, which greatly exceeds that of water electrolysis. Therefore, fuel cells have received more interest than water electrolysis. Technologies are generally developed in fuel cell research and then transferred to water electrolysis. Therefore, we studied fuel cell research publication data in the same way and analyzed the trends of all fuel cell research topics [18]. By comparing them, we forecasted future trends of water electrolysis research.
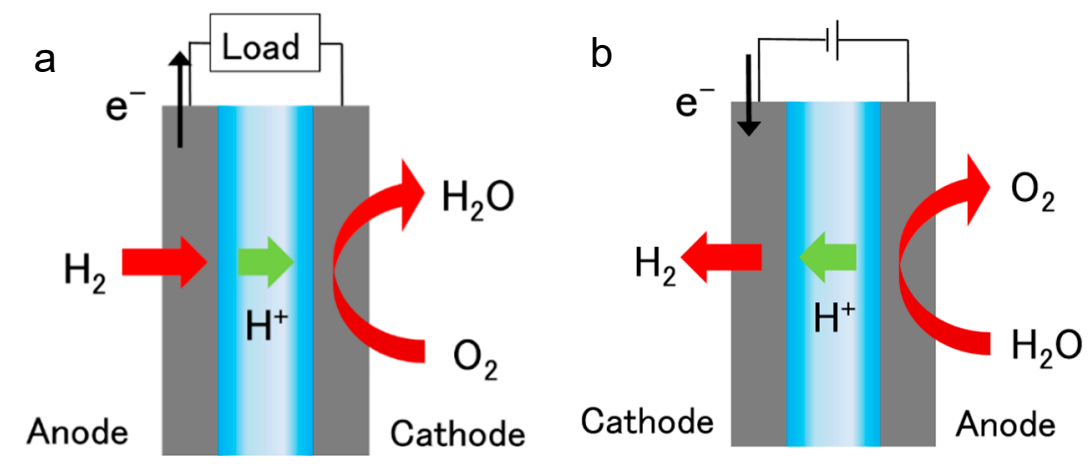

Figure 1. Schematic of (a) a water electrolyzer; and (b) a fuel cell (examples of a polymer electrolyte water electrolyzer and a polymer electrolyte fuel cell, respectively). 


\section{Method}

We collected bibliographic data from water electrolysis studies. Academic papers, including their title, publication year, abstract, journal, and references, were retrieved from the Science Citation Index Expanded (SCI-EXPANDED), which was compiled by the Thomson Reuters Institute for Scientific Information (ISI). We used data collected using the query "(electrolysis OR electrolyser OR electrolyzer) AND (water OR hydrogen)" in October 2016.

Our analytical procedure was as follows [11]: (1) data from academic papers were downloaded; (2) We constructed citation networks by treating the papers as nodes and citations as links. According to a previous study, intercitation, also referred to as direct citation, is the best approach for detecting emerging trends [19]. Only the data for the largest graph component were used for direct analysis; we eliminated data that were not linked to any other papers in step (3). After extracting the largest connected component; in step (4), the network was divided into clusters following the topological clustering method of Newman's algorithm, which extracts tightly knitted groups of nodes [20]. Newman's algorithm uses the following equation:

$$
Q=\sum_{s=1}^{M}\left[\frac{l_{s}}{l}-\left(\frac{d_{s}}{2 l}\right)^{2}\right]
$$

where $Q$ is the independence of the module, $M$ is the number of clusters, $s$ is the given cluster, $l$ is the number of links in the whole network, $l_{s}$ is the number of links between both nodes within cluster $s$, and $d_{s}$ is the sum of the links of the nodes in cluster $s$. In Newman's algorithm, clusters are divided into subgroups to maximize $Q$. In Equation (1), the probability of random links is subtracted from the probability that reference links exist within cluster $s$. This algorithm identifies well-separated clusters within the research area. These procedures can be conducted again for sub-clusters. In Section 3, the main clusters that were classified once are examined as whole trends. In the subsequent sections, clusterizations of the main clusters were repeated for any purpose. The topic of each cluster was confirmed based on keywords in the abstract.

We added hub papers among the citation network as references in the explanation of each cluster. Therefore, in case you investigate specific studies beyond the quoted papers, it is good to read the references in the hub papers and papers that cite the hub papers.

The number of studies published in each year for the clusters was fitted by the Bass model, which allows for an easy understanding of research trends [21,22]. The curve fitting data exclude publications in 2016 because they do not include full studies; therefore, they are not suitable for analyzing publication numbers per year. Data curves that do not show the top of the peak or enough publications are not suitable for Bass models, thus we did not fit such curves.

\section{Water Electrolysis Research Perspective}

\subsection{Initial Classification into Main Research Areas}

Approximately 12,000 papers were collected in total. The papers were divided into several clusters, as shown in Figure 2. The topics of these clusters include "purification of water by electrolysis", "cold fusion", and "aqueous electrophoretic deposition", which are less relevant to water electrolysis. These clusters were manually removed from the analysis presented in this review. The focused clusters were re-clusterized in the same manner and divided into six clusters, as shown in Table 1 . The total number of publications is 5628 , and the average published year is 2009.6 .

The six main clusters cover four main water electrolyzers: the alkaline water electrolyzer (AWE), polymer electrolyte membrane water electrolyzer (PEME), solid oxide electrolyzer (SOEC, which is equivalent to the solid oxide electrolyzer "cell"), and microbial electrolyzers (MEC, which is often referred to as a microbial electrolyzer "cell"). The AWE, PEME, SOEC, and MEC have several similar components to the alkaline fuel cell (AFC), polymer electrolyte fuel cell (PEFC), solid oxide fuel cell 
(SOFC), and the microbial fuel cell (MFC), respectively. Techniques developed in fuel cell research are frequently applied to electrolysis. Although MEC is a slightly different class of electrolysis, as described later, we have included it in this review as it is suitable for large-scale hydrogen production generated from sustainable energy, which is the aim of this review. Cluster III "Anode and acid-stable cathode for AWE and PEME" appeared separately, which focuses on mutual catalysts for AWE and PEME. Cluster VI "Hydrogen production based on renewable energy" covers the whole practical renewable energy system. They have also received great attention and are classified as clusters by studying network citations among papers.

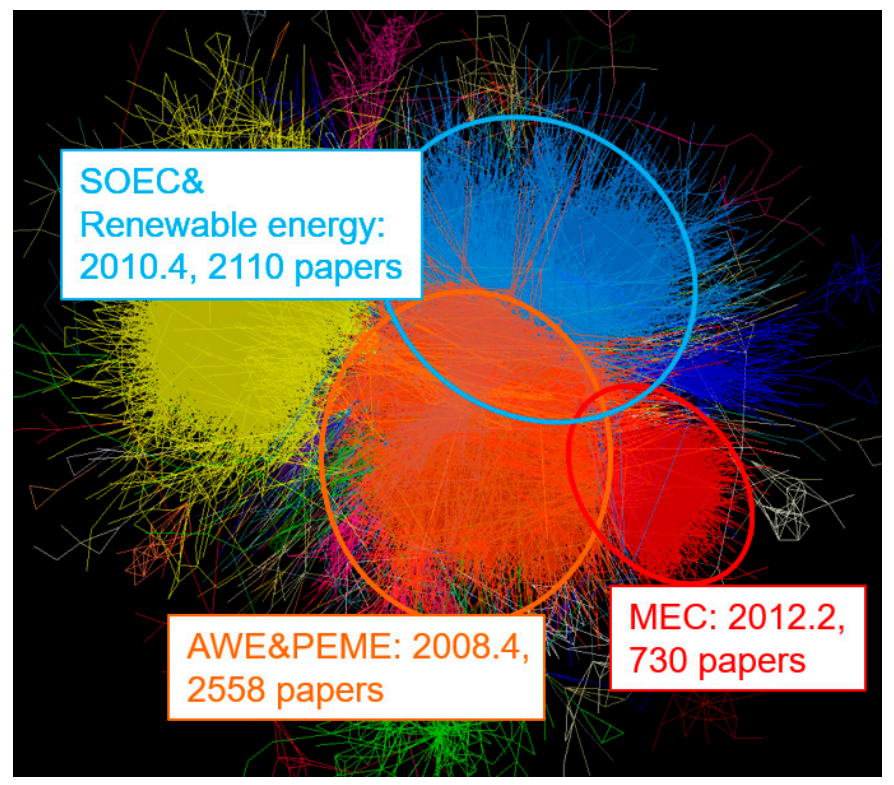

Figure 2. Perspective relationship between each cluster in water electrolysis studies as described by the reported method [23]. Each paper is depicted as a dot, and the line between two dots indicates that either or both of two dots cite the other. Dots that cite or are cited by others are closer, according to the previously reported algorithm [23], which results in the distinction of separated clusters. The orange, blue, and red regions correspond to the AWE \& PEME (clusters I, II, and III), SOEC \& Renewable energy (clusters IV and VI), and MEC research areas, respectively. The research topic of the yellow region is "Electrochemical oxidation and degradation of organics and pollutants in Water", which is irrelevant to water electrolysis and not investigated in this review. The data associated with each cluster covers the average publication year and publication count.

Table 1. The main clusters of water electrolysis studies.

\begin{tabular}{cccc}
\hline Cluster & Research Topic & Number of Publications & Average Publication Year \\
\hline I & System and cathode for AWE & 1088 & 2004.1 \\
II & System for PEME & 741 & 2009.4 \\
III & Anode and acid-stable cathode for AWE and PEME & 669 & 2012.9 \\
IV & SOEC & 741 & 2011.2 \\
V & MEC & 730 & 2012.2 \\
VI & Hydrogen production based on renewable energy & 750 & 2009.9 \\
\hline
\end{tabular}

\subsection{Brief Explanation of Each Electrolysis Type}

Here, we briefly introduce each type of water electrolysis system.

\subsubsection{Brief Explanations of AWE}

The largest cluster covers the AWE, which is composed of an anode and cathode immersed in an alkaline solution, generally $20-30 \%$ potassium hydroxide $(\mathrm{KOH})$. These are also components of an AFC. 
They operate at temperature below $100^{\circ} \mathrm{C}$ and atmospheric pressure. The two electrodes are separated by a diaphragm that conducts hydroxide ions $\left(\mathrm{OH}^{-}\right)$through a $\mathrm{KOH}$ solution, and keeps oxygen and hydrogen separated to prevent recombination. This technology is the most mature for hydrogen production up to the megawatt range at a commercial level. However, it has drawbacks due to the diaphragm. High ohmic loss occurs across a diaphragm immersed in alkali solution and limits the maximum current density. Moreover, the diaphragm cannot completely prevent oxygen and hydrogen from mixing. Therefore, a high pressure cannot be achieved, which would otherwise be beneficial for a bulky stack design. In addition, the permeation of product gas allows oxygen and hydrogen to recombine and decreases Faraday efficiency. Despite these detriments, this type of electrolyzer is the most common because it does not require expensive materials. The alkaline conditions allow us to use other affordable metals such as nickel avoiding those of the platinum group. The $\mathrm{KOH}$ solution for the electrolyte is also affordable.

\subsubsection{Brief Explanations of PEME}

The second largest cluster covers PEME research. A PEME contains an anode and cathode that are separated by a polymer electrolyte membrane (PEM). They operate at approximately $100{ }^{\circ} \mathrm{C}$, which is the same as an AWE. The PEM is often composed of Nafion, a common electrolyte used in PEFC. Nafion has sufficient proton conductivity to achieve electric density beyond $2 \mathrm{~A} \mathrm{~cm}^{-2}$ [24]. Moreover, PEM can separate product gases, thus enhancing its Faraday efficiency to approximately $100 \%$. In addition, PEM allows for operation at high pressure, which is suitable for scaling-up and compressing hydrogen gas for transport. The operation pressure can be elevated to approximately 100 bar; however, at this pressure the PEM needs to be thick, resulting in higher proton conductivity resistance. Operation at a high pressure reduces the relative volume of product gas bubbles and their resulting ohmic resistance. However, the catalyst needs stable, highly acidic conditions produced by the PEM. Therefore, an expensive platinum-group metal would be used; platinum is employed in the hydrogen evolution reaction (HER), as well as PEFC, while iridium oxide is used in the oxygen evolution reaction (OER) due to its high reactivity and stability. Studies in this area focused on catalysts composed of an affordable metal with high reactivity and stability under acidic condition.

\subsubsection{Brief Explanations of SOEC}

A SOEC is composed of an anode and cathode separated by an $\mathrm{O}^{2-}$ conducting electrolyte. The materials used in SOEC are similar to those used for SOFC. Yttria-stabilized zirconia (YSZ), $\mathrm{Ni}-\mathrm{YSZ}$, and LSM (lanthanum strontium manganite)-YSZ are generally used as the electrolyte, anode, and cathode respectively. The operation temperature is much higher $\left(800-1000{ }^{\circ} \mathrm{C}\right)$ than that of AWE and PEME, because the $\mathrm{O}^{2-}$ conductivity of common electrolytes is not sufficient at low temperatures. SOEC produces hydrogen at a high Faraday efficiency of approximately $100 \%\left(1.07 \mathrm{~V}, 0.3 \mathrm{~A} \mathrm{~cm}^{-2}\right)$ [25]. However, over long-term operation, a SOEC degrades faster than a SOFC [26]. Degradation mainly occurs at the anode; high produced oxygen partial pressure occurs at the electrode/electrolyte interface, which causes the electrode to delaminate, although this can be limited when the current density is low $1 \mathrm{~A} \mathrm{~cm}^{-2}$ [27]. SOEC studies have focused on improving stability at a high current density.

\subsubsection{Brief Explanations of MEC}

A MEC can produce not only hydrogen but also various useful organic chemicals. Furthermore, in case that biomass is fueled, a MEC can utilize the chemical energy of biomass as support of electrical energy, which distinguishes MEC from the other three main electrolyzers. Thus, the voltage required in the conversion from biomass into useful organic chemicals is lower than that of chemicals produced from $\mathrm{H}_{2} \mathrm{O}$ and $\mathrm{CO}_{2}$. Therefore, MECs can theoretically produce hydrogen from a low energy input: $0.6-1 \mathrm{kWh} / \mathrm{m}^{3} \mathrm{H}_{2}$ [28,29], however, other water electrolysis systems require an input of 4.5-50.6 kWh $/ \mathrm{m}^{3} \mathrm{H}_{2}$ [29]. There are two types of MEC; the organic reactant is either supplied to the cathode or anode. In the former, the anode evolves $\mathrm{O}_{2}$ and the cathode produces value-added 
organic chemicals, such as methane, acetate, ethanol, or formic acid, which could be the reverse of the reaction used in MFC. The latter produces pure hydrogen from $\mathrm{H}_{2} \mathrm{O}$ in the cathode and releases organic products, such as $\mathrm{CO}_{2}$, in the anode. The anode in a MEC is not exposed to oxygen, while that of MFC is [30]. In addition, the anodes in MECs are microbial biocatalysts on carbon-based materials that can conduct electricity and do not require any precious metals, while the cathode is often composed of platinum. Therefore, the bioanode microbial community in the latter case tends to be anaerobic. A membrane-less MEC has been investigated to reduce ohmic loss and avoid the generation of a $\mathrm{pH}$ gradient from the electrolyte membrane, reducing performance. MEC converts hydrogen methane, which contaminates the produced hydrogen gas. The challenges of using a MEC are to achieve the high hydrogen production rate (which can reduce methane production), low cost of the electrolyte membrane and platinum in the cathode, and long-term stability.

\subsection{Trends of Main Studies}

The number of publications per year of the six topics in Table 1 were sought to evaluate the enthusiasm for each topic (Figure 3).
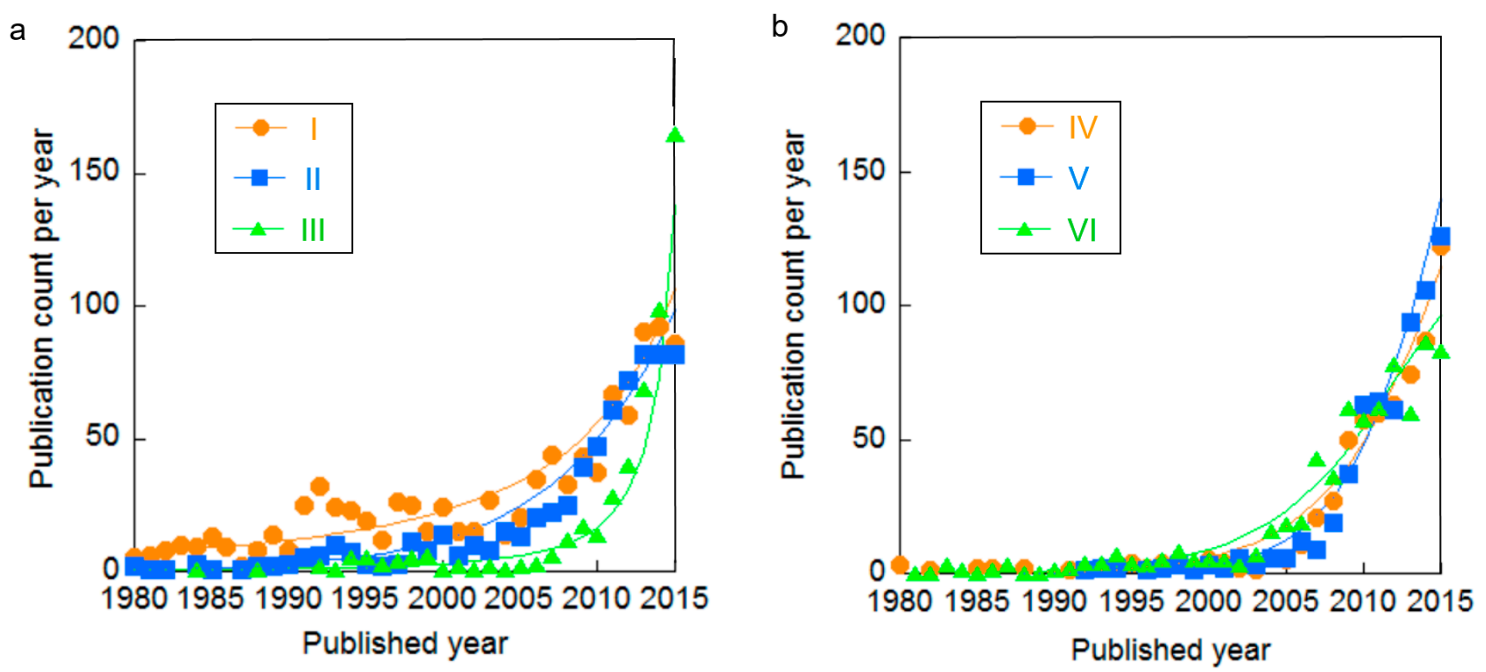

Figure 3. Publication count per year of the main research clusters with curve fittings: (a) I, II, and III (b) IV, V, and VI.

Overall, the number of publications within all research areas in the water electrolysis field has increased since 2000, which could be due to recent keen attention to renewable energy.

Of all water electrolysis systems, cluster I "AWE" has the longest history, and AWE research began in the 1950s. The number of publications per year increased at the beginning of the 1990s; however, research did not continue expanding at the same rate. The number of publications per year in cluster II "PEME" also increased from 1990, which is when PEFC research areas also began to expand. Although the number of both AWE and PEME publications per year accelerated again from 2000, as well as those of other clusters, the rates of increase are not as rapid as those of other clusters, and the number of publications appears to have plateaued. Meanwhile, cluster III "Anode and acid-stable cathode for AWE and PEME", which covers mutual technologies between AWE and PEME, expanded much faster than the others, especially from 2010. This research area should receive focus as it is of great interest among AWE and PEME researches. Cluster IV "SOEC" also began to increase from around 2000, and is still growing at a rapid rate. Cluster V "MEC" has since significantly developed from around 2005. In 2011, the total amount of publications regarding each electrolyzer type descended as follows: MEC $>$ SOEC $>$ AWE $\geq$ PEME, which is almost the reverse of the order at the beginning, although cluster III including catalyst research of AWE and PEME was not considered. Cluster VI, 
"Hydrogen production based on renewable energy", has expanded since 2005, but the rate of increase appears to have recently plateaued.

\section{Perspective and Emerging Technologies of Each Water Electrolyzer Types}

The six clusters in Table 1 were re-clusterized in the same manner into several groups to analyze their research trends. In addition, they were further divided until the topic of the cluster was restricted to one specific study. The information of a subdivided cluster, including the number of publications and average publication year, enables us to evaluate a specific study included in the cluster. We defined an emerging technology as that included in a cluster with an average publication year after 2012 and two years after each main cluster in Table 1 . The emerging technologies from the main clusters are introduced in this section.

\subsection{Cluster I "System and Cathode for AWE"}

Cluster I, which focused on AWE, was re-clusterized into three large and four small clusters, as shown in Table 2. The three large clusters are clusters I-A "AWE System," I-B "Metal alloy and metal composite cathodes," and I-C "Fabrication, characterization of nickel alloy electrodes, and kinetic studies on HER." Their average years of publication are all old, however, in cluster I-A, several review papers have been published since 2010, for example, "Recent progress in alkaline water electrolysis for hydrogen production and applications" reported by Kai Zeng [4]. In addition, cluster I-C also includes several reviews that focused on the material structure of nickel alloy catalysts and analysis on the HER mechanism at the catalysts [31]. These suggest that AWE has recently begun to receive attention again. Meanwhile, cluster I-D "Electrodeposition of hierarchically structured nickel composite electrode" is younger than the others. The topic of this cluster is the electrodeposition of nickel or nickel-based catalysts to enhance HER efficiency by controlling the nanostructure or hierarchal structure of the nickel composite [32,33]. Although this cluster is still small and the hub paper in its citation network is not clear, it covers an emerging AWE technology. Cluster I-E "Ruthenium dioxide-based cathode" investigated the properties of $\mathrm{RuO}_{2}$ as a cathode for $\mathrm{AWE}$. $\mathrm{IrO}_{2}$ is one of the best catalysts for OER due to its reactivity and stability under acidic conditions. However, iridium is a scarce element; platinum is 10 times more abundant than iridium. The cost of iridium represents a considerable portion of the total system cost. However, ruthenium is relatively affordable, and $\mathrm{RuO}_{2}$ is more active than $\mathrm{IrO}_{2}$. However, $\mathrm{RuO}_{2}$ in cathodes corrodes as it forms $\mathrm{RuOH}$ when it is exposed to reverse currents when the power is shut off for maintenance [34-36]. Several studies have focused on stabilizing $\mathrm{RuO}_{2}$ by combining it with other oxides, such $\mathrm{TiO}_{2}$ or a small amount of $\mathrm{IrO}_{2}$. The main issue of $\mathrm{RuO}_{2}$ is not its usage as the cathode, but its use as the anode, which is where the reverse current is generated. This was investigated in cluster III-2. As shown by the small number of publications and old average year of publication, this cluster has not received considerable attention. Cluster I-F "Gas bubble on electrode" contains studies about the gas bubbles produced on electrodes. Gas bubbles cause overpotential and are inevitable when liquid water is used, thus, they should be removed quickly. The influences of gravity, mass flow, and a magnetic field on the electrode are investigated here [37,38]. The number of publications is slightly increasing, but the absolute number published per year is small, and its average publication year is the second oldest of the subclusters. This research should be considered "close to mature". Cluster I-G focuses on water electrolysis through an anion exchange membrane, which is a reverse reaction to that in a solid alkaline fuel cell (SAFC) [39,40]. The solid membrane has the potential to allow operation at a high pressure and reduce its cell size in a similar manner to PEME. Although the membrane is not affordable as a $\mathrm{KOH}$ solution is, this type of electrolyzer retains the merit of AWE that low-cost metals can be utilized under alkaline conditions. SAFC is an emerging technology in PEFC research, and novel membranes are being developed with suitable chemical and thermal stability. Membranes developed in SAFC research can be introduced to this type of water electrolyzer. This type of system should also receive focus as an emerging technology. The emerging technologies in cluster I are clusters I-D “Electrodeposition of hierarchically structured 
nickel composite electrodes" and I-G "Anion exchange polymer membrane electrolysis cell", which should receive attention.

Table 2. Main clusters in cluster I.

\begin{tabular}{cccc}
\hline Cluster & Research Topic & Number of Publications & Average Publication Year \\
\hline I-A & AWE System & 310 & 2002.5 \\
\hline I-B & Metal alloy and metal composite cathodes & 232 & 2001.4 \\
\hline I-C & $\begin{array}{c}\text { Fabrication, characterization of nickel alloy } \\
\text { electrodes, and kinetic studies on HER }\end{array}$ & 232 & 2007.4 \\
\hline I-D & $\begin{array}{c}\text { Electrodeposition of hierarchically structured } \\
\text { nickel composite electrodes }\end{array}$ & 33 & 2012.3 \\
\hline I-E & Ruthenium dioxide-based cathode & 30 & 2007.1 \\
\hline I-F & Gas bubble on electrode & 118 & 2005.9 \\
\hline I-G & Anion Exchange Membrane Electrolysis Cell & 67 & 2012.0 \\
\hline
\end{tabular}

\subsection{Cluster II "System for PEME"}

Cluster II, focusing on PEME, was re-clusterized into four clusters, as shown in Table 3, and the number of publications per year in these clusters is presented in Figure 4. Cluster II-A "Fundamental studies and models on PEME" focuses on the design of cells, stacks, and systems, optimized by experiments and modeling. In addition, it contains many recent review papers, such as the central review "A comprehensive review on PEM water electrolysis" reported by Marcelo Carmo [24]. This cluster has a long history and large number of publications. Therefore, the average publication year is old, and the publication rate has slowed in recent years. This suggests that the whole PEME design is mature, but it is receiving much attention in reviews. Cluster II-B "Iridium-based oxide for OER in anode" focuses on alloying iridium oxide with metals such as Ru [41] and Sn [42]. This composite has been investigated as an OER anode, which is one of the most important factors for high PEME efficiency. The number of publications per year in this cluster has recently increased. Regenerative fuel cells (RFC) are the topic of cluster II-C, which can be utilized as both water electrolyzers and fuel cells [43-45]. RFC can reduce the total components and weights of the power generator/accumulator, which is beneficial for some applications, such as use in a space shuttle. However, RFC is often optimized for operating in one mode, and generally does operate very efficiently in the other. Figure 4 shows that the number of publications regarding RFC began to increase in 2004, although the total number of publications number has not expanded as much. Cluster II-D “Material studies on components of PEM for high temperature water (steam) electrolysis" focuses on steam electrolysis by PEME at a high temperature. The elevated temperature significantly improves the energy efficiency of water electrolysis because of the enhanced electrode kinetics, heat recovery facilitated by steam, and reduced thermodynamic energy at the electrode. However, the high temperature also corrodes materials [46]. Stable materials for the bipolar plate under these operation conditions are sought in this cluster. In addition, when the temperature exceeds boiling point, the electrolyte membrane is dehydrated, which results in low electrolyte proton conductivity and high ohmic resistance. Phosphoric doped polybenzimidazole (PBI) [47] and perfluorosulfonic acid (PFSA) membranes [48] are tested in this cluster, which have high proton conductivity even under low humidity conditions. Although the recent growth of cluster II-D is not as rapid as that of cluster II-A, it was formed in 2006 and the total number of publications it contains is small. This cluster may not receive current focus and its average publication year is young, therefore it is an emerging technology. In addition, we detected one more emerging technology: cluster II-1 "Hydrogen production from electrolysis of a water-alcohol solution (publication number: 55, average publication year: 2012.6)." This cluster investigates the performance of water electrolysis using a water-alcohol solution, including methanol [49], ethanol [50], and glycerol [51]. The chemical energy of alcohol decreases the voltage required for water electrolysis; 
methanol can be converted to $\mathrm{H}_{2}$ and $\mathrm{CO}_{2}$ at $0.02 \mathrm{~V}$ at room temperature and atmospheric pressure, which is much lower than the $1.23 \mathrm{~V}$ required for water electrolysis. Although $\mathrm{CO}_{2}$ is produced by this process, studies in this cluster assume that alcohols originate from biomass. Thus, this cluster can be considered to be a derivative of MEC, although no microbiome is employed here. This method is also referred to as electrochemical reforming. Currently, the most cost-effective method of producing hydrogen at a large scale is steam reforming natural gas. Electrochemical reforming is quick and convenient, and also suitable for small- and medium-scale hydrogen production. These two topics should receive focus as emerging technologies.

Table 3. Main clusters in cluster II.

\begin{tabular}{cccc}
\hline Cluster & Research Topic & Number of Publications & Average Publication Year \\
\hline II-A & Fundamental studies and models on PEME & 430 & 2008.5 \\
\hline II-B & Iridium-based oxide for OER in anode & 197 & 2011.3 \\
\hline II-C & RFCs & 80 & 2008.7 \\
\hline II-D & $\begin{array}{c}\text { Material studies on components of PEME for } \\
\text { high-temperature water (steam) electrolysis }\end{array}$ & 20 & 2012.9 \\
\hline
\end{tabular}

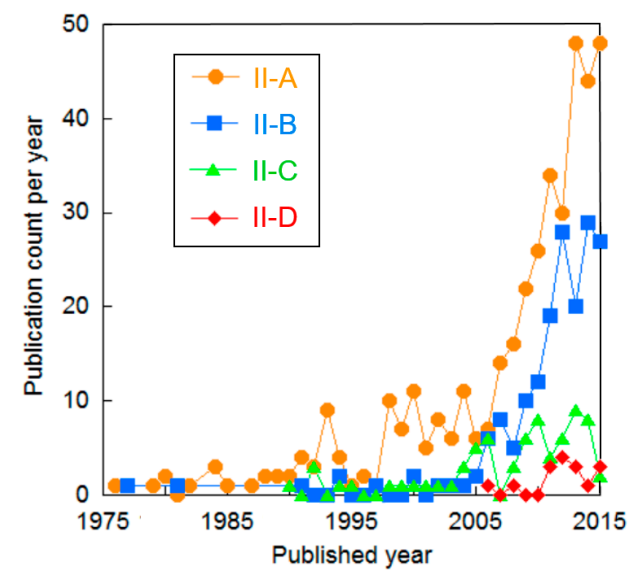

Figure 4. Number of publications per year within the main clusters of cluster II.

\subsection{Cluster III "Anode and Acid-Stable Cathode for AWE and PEME"}

\subsubsection{Perspective of Cluster III}

Cluster III, which focuses on catalysts for AWE and PEME, was divided into four clusters, as shown in Table 4. The number of publications per year within the clusters is plotted in Figure 5. Cluster III-A "Metal oxide catalyst for OER" focuses on the use of metal oxides, such as cobalt [52], nickel [53], manganese [54], and copper [55], as OER catalysts. The average publication year of cluster III-A is recent, and includes several emerging technologies that will be introduced later. Cluster III-B "Theoretical screening of metal oxides for OER" also focuses on metal oxide catalysts, but with different approaches; this cluster contains theoretical screenings. Ab initio calculations have been used to assess the catalytic activity of metal oxides and determine which is the most suitable based on a "volcano plot", which shows the relationship between the adsorption of reactants and desorption of products (both are important factors for catalytic activity) [36,56]. Clusters III-A and III-B have both grown rapidly since 2010 and should be considered topics of great interest. However, cluster III-C "Binary or ternary oxide for OER", which focuses on binary or ternary oxides composed of $\mathrm{Co}, \mathrm{Fe}, \mathrm{Ni}, \mathrm{Mo}, \mathrm{Cr}, \mathrm{Cu}$, $\mathrm{La}$, and $\mathrm{Sr}$ [57-61], does not appear to be an area of current interest, because its average publication year is old and the number of publications per year is decreasing. This could be because there are too many patterns, and the studies are not systematical. This topic could dominate after fundamental 
studies, such as those in clusters III-A and III-B, are completed. Cluster III-D "Carbide, phosphide, sulfide, and selenide for HER" does not focus on oxides, but on composites of transition metals ( $\mathrm{Co}, \mathrm{Ni}$, Mo, and W) and typical elements (C, P, S, and Se) [62-67]. The number of publications in this cluster exponentially increased from 2013, thus cluster III-D covers a research area that receives great interest.

Table 4. Main clusters in cluster III.

\begin{tabular}{cccc}
\hline Cluster & Research Topic & Number of Publications & Average Publication Year \\
\hline III-A & Metal oxides for OER & 188 & 2013.8 \\
III-B & Theoretical screening of metal oxides for OER & 173 & 2013.6 \\
III-C & Binary or ternary metal oxides for OER & 96 & 2006.5 \\
III-D & Carbide, phosphide, sulfide, and selenide for HER & 183 & 2014.7 \\
\hline
\end{tabular}

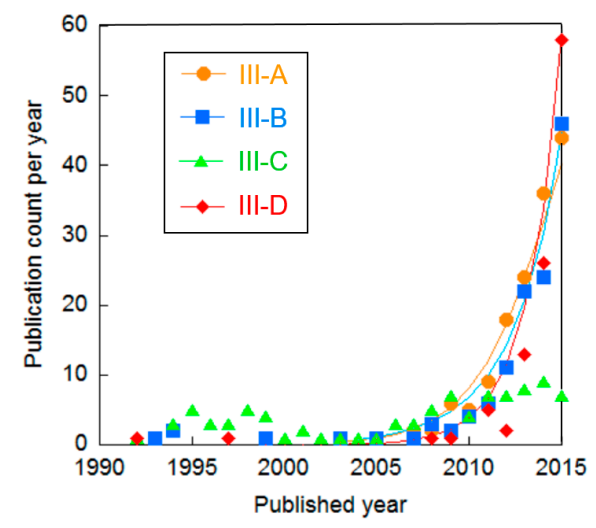

Figure 5. Publication count per year of the main clusters in cluster III, with curve fittings for clusters III-A, III-B, and III-D.

\subsubsection{Emerging Technologies in Cluster III}

The clusters in Table 4 were divided repeatedly to identify emerging technologies. The extracted emerging technologies are presented in Table 5.

Table 5. Emerging technologies in the studies of cluster III.

\begin{tabular}{|c|c|c|c|}
\hline Cluster & Research Topic & Publication Number & Average Publication Year \\
\hline III-2 & $\mathrm{RuO}_{2}$ for OER in PEME & 61 & 2014.3 \\
\hline III-4 & Nickel and cobalt phosphide for OER and HER in acid condition & 52 & 2015.4 \\
\hline III-5 & Mn oxides on conductive materials in alkaline condition & 42 & 2013.6 \\
\hline III-6 & Metal disulfide or diselenide for HER & 50 & 2014.9 \\
\hline
\end{tabular}

Cluster III- 1 focuses on Co oxides catalysts. Cobalt is not a noble metal, but it has high catalytic power for splitting water. Co-based complexes first received attention for their high reactivity, although grafting these complexes is difficult and results in decreased reactivity and low stability. Considerable effort has been expended to develop Co oxides as a heterogeneous inorganic compound with sufficient activity for OER. The influence of the compound's nanostructure, which is typically a thin film prepared by electrodeposition to overcome its poor conductivity, on the activity of Co oxides has been investigated [52,68]. These compounds are unstable in an acidic solution, and are utilized for AWE.

Cluster III-2 focuses on the use of a $\mathrm{RuO}_{2}$ anode for OER, especially in PEME [69,70]. This is different from cluster I-E, which focused on using $\mathrm{RuO}_{2}$ as a cathode for HER. As discussed regarding cluster I-E, $\mathrm{IrO}_{2}$ is the best catalyst in terms of activity and stability, although it is expensive. $\mathrm{RuO}_{2}$ is 
employed as an alternative and shows good activity; however, it corrodes to $\mathrm{RuOH}$ in OER. The stability is improved when other oxides, such as $\mathrm{CeO}_{2}$ [71] and a small amount of $\mathrm{IrO}_{2}$ [41], are added. For example, small amounts of $\mathrm{IrO}_{2}(20 \%)$ can drastically reduce the corrosion rate [72].

Clusters III-3 and III-4 examined Ni-based catalysts. As introduced in AWE, Ni exhibits electro-catalytic activity towards OER in an alkaline solution. Ni-Fe exhibits high catalytic activity, and is still a promising catalyst for OER in an alkaline solution (cluster III-3) [73,74]. Cluster III-4 focuses on $\mathrm{Ni}_{2} \mathrm{P}$, which has high catalytic activity in HER and OER [75]. Notably, $\mathrm{Ni}_{5} \mathrm{P}_{4}$ is stable, even under strongly acidic conditions $\left(1 \mathrm{M} \mathrm{H}_{2} \mathrm{SO}_{4}\right)$, and exhibits high catalytic activity despite that it does not contain a noble metal [76,77]. In addition, $\mathrm{CoP}$ has also been reported as an acid-stable catalyst for HER and OER [62]. Although the current density and duration in their stability tests are restricted, these materials have the potential to become more stable. The average publication year of this cluster is the most recent investigated in this paper. This topic should thus be considered the key emerging technology.

In cluster III-5, $\mathrm{MnO}_{2}$ has also been investigated here as an OER catalyst in alkaline solution [54,78]. $\mathrm{MnO}_{2}$ is examined as an alternative catalyst that more affordable even than cobalt oxides. Although bulk $\mathrm{MnO}_{2}$ suffers from poor electrical conductivity, a thin film of $\mathrm{MnO}_{2}$ deposited on conductive materials works sufficiently. Then, $\mathrm{MoO}_{2}$ on conductive catalyst supports, e.g., carbon nanotube $(\mathrm{CNT})$, is investigated [79]. These experiments are performed in alkaline condition because $\mathrm{MnO}_{2}$ corrodes in acid solution.

Cluster III-6 investigated metal disulfides and diselenides, including $\mathrm{CoS}_{2}, \mathrm{FeS}_{2}, \mathrm{NiS}_{2}, \mathrm{WS}_{2}$, and $\mathrm{CoSe}_{2}[63,65,80,81] . \mathrm{MoS}_{2}$ has received attention for its high reactivity in HER and stability under acidic conditions, while being composed of affordable elements. $\mathrm{MoS}_{2}$ exhibits catalytic activity in edge sites, and the reaction mechanism of this is well-understood [82,83]. Methods of improving catalytic activity have been explored, such as doping transition-metal $\mathrm{MoS}_{2}$ [84]. This cluster is the second most recent, following cluster III-4, in terms of average publication year. This should be also considered as an emerging technology.

Cluster III-7 focuses on precious metal-free and acid-stable catalysts for HER, such as $\mathrm{W}_{2} \mathrm{C}$ [85] and $\mathrm{Mo}_{2} \mathrm{C}$ [67]. Tungsten carbides are also utilized for catalytic support of the platinum monolayer [86,87]. The high Pt layer activity of tungsten carbides is explained by their "Pt-like" properties.

In cluster III-8, different $\mathrm{Cu}$ complexes exhibit high OER activity $[88,89]$. These studies indicate that $\mathrm{Cu}$ can be a promising catalyst for HER as it is abundant and low cost, although, for practical use, $\mathrm{Cu}$ complexes should be developed as an electrode, or a heterogeneous $\mathrm{Cu}$ compound would need to be developed. This cluster examines the fundamental aspect of $\mathrm{Cu}$-based catalysts.

\subsection{Cluster IV "SOEC"}

Cluster IV, which discusses SOEC, was re-clusterized into four clusters, as shown in Table 6, and their numbers of publications per year are shown in Figure 6. Cluster IV-A "Performance of SOEC" focused on practical research, rather than fundamental research, such as the invention of novel materials. This cluster was subdivided into two further clusters: clusters IV-A-1 "Optimization of whole SOEC cell based on modeling (92 publications, average publication year 2010.5)" [90,91] and IV-A-2 "Co-electrolysis of $\mathrm{CO}_{2} / \mathrm{H}_{2} \mathrm{O}$ for $\mathrm{CH}_{4}$ production by SOEC (publication number: 77, average publication year: 2012.9)" [92,93]. Although the average publication year of cluster IV is relatively recent, the hub papers of the citation network in this cluster are old. This indicates that this topic has received recent attention, however central papers have recently been published and the direction of this topic is undetermined. Cluster IV-B covers the use of heat and electricity from a nuclear power plant in SOEC, which is also practical research $[94,95]$. This cluster includes research about scaling up hydrogen production [96]. This topic appears to be of less focus, as indicated by its old average publication year, low number of publications, and recently-decreasing number of publications per year. Research of SOEC systems is restricted to clusters IV-A and IV-B. The total number of publications in clusters IV-A and IV-B is limited, and notable research that prompts 
the publication of new research has not yet been published within them. Therefore, studies on the practical performance of SOEC do not receive as much enthusiastic focus as other types of water electrolyzers. Cluster IV-C "Materials of SOEC" studies the application of materials in SOEC, which are introduced from SOFC research. Cluster IV-C can be also subdivided to three categories: IV-C-1 “ $\mathrm{La}_{0.75} \mathrm{Sr}_{-} \mathrm{Cr}_{0.5} \mathrm{Mn}_{0.5} \mathrm{O}_{3}$ (LSCM) cathode for SOEC (publication number 74, average publication year 2013.0)" [97,98], IV-C-2 "SOEC using proton-conducting oxides (publication number: 71, average publication year: 2009.0)" [6,99], and IV-C-3 “ $\mathrm{LaGaO}_{3}$ electrolyte for SOEC (publication number: 40, average publication year 2008.5)" [100,101]. Only cluster IV-C-1, focusing on LSCM, is recent. It appears that the recent progress of SOFC research about LSCM has been applied to SOEC, while other SOFC research topics have not. Cluster IV-D "Degradation of anode in SOEC" should be an original SOEC topic rather than just an application transferred from SOFC technologies. SOEC degrades faster than SOFC during long-term operation. Degradation mainly occurs at the anode; the high partial pressure of produced oxygen occurs at the electrode/electrolytes interface, which causes the electrode to delaminate. Cluster IV-D focuses on understanding the degradation mechanism to improve stability [102,103].

Among the clusters that cover SOEC, emerging technologies were not identified. The most notable cluster should be the youngest, which is cluster IV-C-1 “ $\mathrm{La}_{0.75} \mathrm{Sr}_{-} \mathrm{Cr}_{0.5} \mathrm{Mn}_{0.5} \mathrm{O}_{3}$ (LSCM) cathode for SOEC." Cluster IV-D should be also focused on as a research area receiving particular interest.

Table 6. Main clusters of cluster IV.

\begin{tabular}{cccc}
\hline Cluster & Research Topic & Number of Publications & Average Publication Year \\
\hline IV-A & Performance of SOEC & 193 & 2011.7 \\
IV-B & SOEC using power supplied by nuclear power plant & 92 & 2008.7 \\
IV-C & Materials of SOEC & 187 & 2010.5 \\
IV-D & Degradation of anode in SOEC & 168 & 2012.6 \\
\hline
\end{tabular}

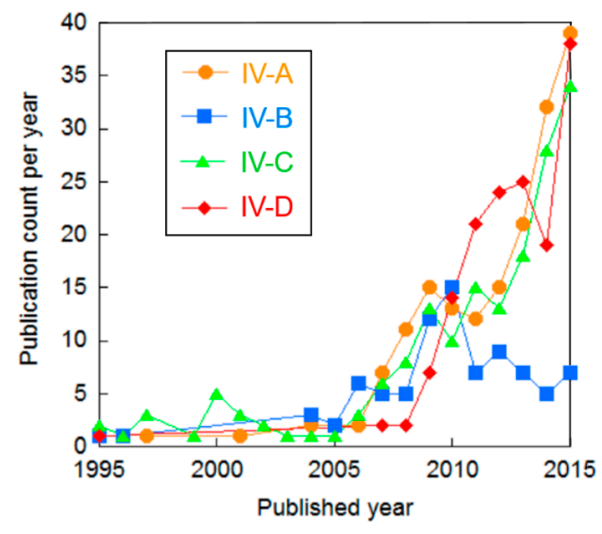

Figure 6. Publication count per year of the main clusters in cluster IV.

\subsection{Perspective and Emerging Technologies of Cluster V "MEC"}

Cluster $\mathrm{V}$, which focuses on MEC, was not divided into groups structured as $-\mathrm{A},-\mathrm{B},-\mathrm{C}$ as other studies were, thus, we subdivided them until each cluster only contained one specific topic. This could be because MEC technologies are in their early stages. MEC studies were finally divided into nine clusters, and small clusters with fewer than 20 publications were ignored.

Cluster V-1 "MEC biocathodes for HER" focused on using different biocathodes in HER, instead of platinum [104,105]. The bacteria studied in this cluster have not been determined, which also suggests that this topic is in its early stages. Cluster V-2 "Nickel cathode for MEC" investigates the use of nickel as a cathode for MEC instead of platinum. Nickel-based catalysts exhibit high catalytic activity, and nickel foam is a common catalyst for use under alkaline conditions [106,107]. Cluster V-3 "Methane production by MEC" investigated the conversion of organic waste or $\mathrm{CO}_{2}$ into 
methane by MEC [108]. Methane production is inevitable in MEC, because the growth of methanogens is fast, although methane production can be suppressed if the hydrogen production rate is high enough [109]. Methane production is usually a problem as it can contaminate produced hydrogen. In this cluster, methane production is intentional, because methane is widely used as chemical energy. The production of methane by MEC has several advantages: the product gas has a higher methane content than that of other technologies, no additional heat is required, and wastewater with low organic substrate content can be used, which cannot be treated by anaerobic digestion. However, the Faraday efficiency of this process is currently low: around 25\% [110]. Cluster V-4 "Single chamber (membrane-less) MEC" focuses on membrane-less MEC [111,112]. Nafion is generally utilized as a separator membrane and transport proton. However, it can induce a $\mathrm{pH}$ gradient on both the anode and cathode, resulting in overpotential [109], and the cost of electrolytes for large-scale operation of this process is expensive. To avoid the above challenges, membrane-less MEC has been studied. In cluster V-5 "Polymer electrolyte membrane for MEC," several polymer electrolyte membranes (mainly a cation exchange membrane) were tested to improve the performance of MEC based on their $\mathrm{pH}$ and ion transport. Although the use of a membrane has some drawbacks, as mentioned above, it is still useful to separate organic waste from the cathode and obtain pure hydrogen gas. To overcome the challenges, various membranes have been tested in terms of their ion transport, $\mathrm{pH}$, and overall performance $[113,114]$. Cluster V-6 "Combining dark fermentation and MEC" covers hydrogen production with MEC from effluent of the fermentative conversion. Dark fermentation does not require light, and it requires moderate operation conditions and can utilize various organic substrates with low energy demand [115]. However, it has a low hydrogen recovery of approximately 23-25\% due to thermodynamic limitations [116,117]. To increase the efficiency, MEC is utilized to produce hydrogen from effluent from the fermentation $[118,119]$. Meanwhile, cluster V-7 “Light-assisted $\mathrm{H}_{2}$ production with MEC" focuses on assisting MEC with sunlight from a solar cell. Dye-sensitized solar cells (DSSC) are preferentially utilized in research regarding this topic. They can achieve a high recovery efficiency of approximately $80 \%$ [120]. The additional costs of a solar cell are a challenge, and thus studies in this cluster aim to reduce the use of other expensive components such as platinum in cathodes [121]. The main purpose of cluster V-8 "Metal recovery from water with a hydrogen byproduct", is not hydrogen production, but the simultaneous generation of hydrogen gas through the recovery of metal from an aqueous mixture (the complete separation of $\mathrm{Cu}(\mathrm{II}), \mathrm{Co}(\mathrm{II})$, and $\mathrm{Li}(\mathrm{I})$ from aqueous mixtures is a critical step for recycling spent lithium-ion batteries, and consumes a large amount of energy and chemicals) [122]. Cluster V-9 "Microbial electrolysis and desalination cell (MEDC)" focuses on developing MEDC that integrate the microbial desalination of seawater and recovery of energy from organic waste [123,124]. As cluster IV is recent (the average publication year is 2012.2), emerging MEC technologies were not identified. However, the clusters in Table 7 are all recent compared to other water electrolysis clusters, for example, V-2, V-3, and V-9 are more recent than 2013.0. These clusters are all in their early stages and should be noteworthy topics in MEC research.

Table 7. Main clusters in cluster V.

\begin{tabular}{|c|c|c|c|}
\hline Cluster & Research Topic & Number of Publications & Average Publication Year \\
\hline $\mathrm{V}-1$ & MEC biocathodes for HER & 33 & 2012.4 \\
\hline $\mathrm{V}-2$ & Nickel cathode for MEC & 57 & 2012.6 \\
\hline $\mathrm{V}-3$ & Methane production by MEC & 82 & 2013.1 \\
\hline V-4 & Single chamber (membrane less) MEC & 79 & 2012.7 \\
\hline $\mathrm{V}-5$ & Polymer electrolyte membrane for MEC & 23 & 2013.6 \\
\hline $\mathrm{V}-6$ & Combining dark fermentation and MEC & 100 & 2012.1 \\
\hline $\mathrm{V}-7$ & Light-assisted $\mathrm{H}_{2}$ production with MEC & 28 & 2012.9 \\
\hline $\mathrm{V}-8$ & Metal recovery from aqueous mixtures with a hydrogen byproduct & 25 & 2012.9 \\
\hline V-9 & Microbial electrolysis and desalination cell (MEDC) & 23 & 2013.4 \\
\hline
\end{tabular}

\subsection{Cluster VI "Hydrogen Production Based on Renewable Energy"}

Cluster VI, "Hydrogen production based on renewable energy" was re-clusterized into four clusters, as shown in Table 8, and their number of publications per year is shown Figure 7. Cluster VI-A 
"Power management of a stand-alone system for the storage of renewable energy as hydrogen" explores the development of a stand-alone power system based on renewable energy, mainly photovoltaic energy $[125,126]$. The focus of this cluster is not only efficient hydrogen production, but system management to automate power generation. Stored hydrogen is utilized to constantly generate electricity via a fuel cell, such as a PEFC. Both practical operation and assessment by modeling are conducted in this cluster. Cluster VI-B "Hydrogen production based on wind power" focuses on the economic aspect of producing hydrogen by wind power $[127,128]$. This could be because wind power is currently the cheapest renewable energy source. Among the papers in this cluster, the most recent research reports that the cost of hydrogen produced by wind power is $\$ 3.37 \sim \$ 9.00 / \mathrm{kg} \mathrm{H}_{2}$, considering the costs of the water electrolyzer and the rechargeable battery that supports it [129]. Even though the cost of water electrolysis and the rechargeable battery is more ideal, the cost of a wind power plant does not change and becomes dominant; a maximum of $63 \%$ of the total cost is from the wind power plant. Currently, producing hydrogen by steam reforming methane combined with carbon capture and storage to ensure that $\mathrm{CO}_{2}$ is not emitted is more affordable: $\$ 1.87-\$ 2.60 / \mathrm{kg} \mathrm{H}_{2}$. This implies that the cost ratio of water electrolysis is small in large-scale plants. The research topic of cluster VI-C "Direct coupling of solar power and hydrogen generation system" is the direct supply of electricity produced by sunlight to a hydrogen production system without a direct current (DC)/DC converter $[130,131]$. It would be advantageous if an electrolyzer could be simply and efficiently coupled directly to a source of renewable electrical energy, reducing the need for additional electronic systems. However, the energy efficiency of this process is low. There are numerous publications in this cluster, but its average publication year is old. This topic is not currently of great focus. Cluster VI-D “Thermodynamics of renewable energy for hydrogen production" studies the energetic and exegetic efficiency of renewable energy source, especially geothermal energy [132,133]. The geothermal process can directly produce hydrogen from steam electrolysis heated by geothermal energy, and conduct water electrolysis at a low temperature by electricity generated from a geothermal plant. An article reports that the total energy efficiency exceeds 50\% [134]. However, the number of publications has not grown recently.

Overall, the number of publications in cluster VI has increased since 2005, but the number of publications per year appears to have plateaued recently. No emerging technologies were identified in cluster VI. The most recent cluster in Table 8 is cluster VI-B, which could be because wind power is currently the cheapest renewable energy source, and thus receives more attention.

Table 8. Main clusters in Cluster VI.

\begin{tabular}{cccc}
\hline Cluster & Research Topic & Number of Publications & Average Publication Year \\
\hline VI-A & $\begin{array}{c}\text { Power management of a stand-alone system } \\
\text { for storage of renewable energy as hydrogen }\end{array}$ & 228 & 2009.5 \\
\hline VI-B & Hydrogen production based on wind power & 181 & 2011.4 \\
\hline VI-C & $\begin{array}{c}\text { Direct coupling of solar power and hydrogen } \\
\text { generation system }\end{array}$ & 179 & 2008.9 \\
\hline VI-D & $\begin{array}{c}\text { Thermodynamics of renewable energy for } \\
\text { hydrogen production }\end{array}$ & 130 & 2009.8 \\
\hline
\end{tabular}




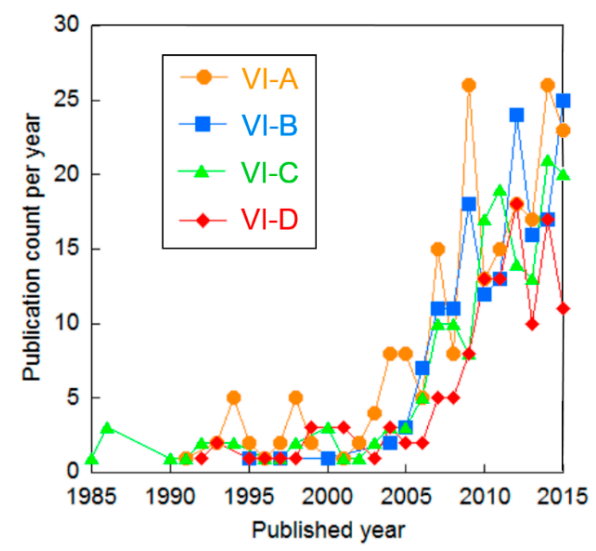

Figure 7. Publication count per year of the main clusters in cluster VI.

\section{Discussion}

\subsection{Overview of Overall Trends in Water Electrolysis Research}

The publication counts of all main clusters are increasing. Clusters III "Anode and acid-stable cathode for AWE and PEME" and V "MEC" have increased rapidly. These research areas are still in their early stages and contain many emerging technologies, as mentioned in Section 4. In MEC research, fundamental studies of components and practical research of the whole system have been conducted simultaneously. MEC can utilize versatile sources, including organic substrates such as seawater, irrigation, and wastewater, which have different components based on their origin. Furthermore, the electricity required for electrolysis can be supplied from renewable energy sources, such as solar or wind power, which also vary spatially. Therefore, MEC systems need to be optimized case by case, and thus, research about the overall system will continue to expand for a while. Cluster III contains fundamental AWE and PEME research, because the studies in this cluster focused on catalyst materials rather than the whole system. This research is compatible with the catalysts used in AFC and PEFC, which could motivate cluster III. Catalysts for PEFC (including SAFC) also receive great attention as a fuel cell technology research area [18], and there are still many catalysts that have not yet been transferred. Cluster III will also continue to receive great attention.

The publications in clusters I "System and cathode for AWE" and II "System for PEME" include several recent review papers, indicating that they are also receiving much attention. This could be because AWE and PEME are suitable for on-site energy storage in areas without sufficient infrastructure. On-site storage needs to be small scale and reliable. AWE has been studied for a long time, and it is well-understood for operation. In the second cluster, PEME also has a long history and vast accumulated knowledge. It is, therefore, reasonable to focus on AWE and PEME as on-site energy storage systems. However, unlike clusters III and V, clusters I and II do not contain many emerging technologies, and the rates at which the number of publications increases are relatively slow. These two clusters are related to the whole system, and their optimization with current technologies is almost sophisticated. Furthermore, the optimization of AWE and PEME systems is less urgent than that of the MEC system, because these systems do not need to consider the diversity of organic substrates. However, the development of cluster III will provide an opportunity to draw attention to clusters I and II, because the new catalysts in cluster III could change the whole system, which needs to be optimized. Moreover, there are several technologies in fuel cell research that have not yet been applied to AWE and PEME, as shown in the review of fuel cell research [18]. Clusters I and II will also receive more attention and become topics of great interest if these technologies are introduced to water electrolysis.

The number of SOEC publications has increased, as well as that of other water electrolysis systems, thus SOEC is receiving attention. However, research of the SOEC system is not as extensive as that 
of other types. This could be because the stability of SOEC is insufficient for long-term operation. SOEC research includes studies about fundamental materials. Stability is reduced due to the harsh conditions in the SOEC anode that generate a large amount of $\mathrm{O}_{2}$ with high partial pressure at a high temperature, which differs from SOFC. Therefore, this is a novel challenge for SOEC that cannot be solved by transferring SOFC technology alone. Moreover, SOEC requires constant energy input to maintain its high temperature, which is not suitable for small- or medium-scale renewable energy storage because the time dependency of renewable energy is not suitable for maintaining a constant temperature at those scales. Current interests in renewable energy surround the development of small-scale systems for each location, which appear to be derived from the high cost of renewable energy. This could also be the reason that research of SOEC systems is not currently receiving much focus. If the anode stability becomes sufficient and large-scale renewable energy storage is required, research of SOEC systems will receive more interest.

\subsection{Comparison with Fuel Cell Technologies}

In this section, we discuss the future water electrolysis research trends based on an overview of fuel cell studies [18]. Over 94,000 studies about fuel cells were published as of 2016, and almost all technologies used for water electrolysis are also used for fuel cell research, which indicates that water electrolysis research has examined the technologies used in fuel cell research. Actually, MFC, and catalysts for AFC (SAFC) and PEFC are expanding the most in fuel cell research, which is a similar pattern to water electrolysis research as the reverse technologies to MEC (cluster V) and catalysts for AWE and PEME (cluster III). This could be because technologies transferred from fuel cell research promote the development of water electrolysis systems. Therefore, it could be possible to forecast future water electrolysis technologies from fuel cell studies.

In the research contained in cluster III, many fuel cell technologies have not yet been transferred. One of the most promising catalysts for water electrolysis is the metal-free N-doped graphene/CNT catalyst, which exhibits high catalytic activity for the oxygen reduction reaction (ORR). This could be also useful for OER, because ORR is the reverse of OER, therefore, catalysts should work in the same manner. The heteroatom-doped graphene/CNT can be substituted by boron, sulfur, or phosphorous, which provides the carbon-based materials with different electronic statuses [18]. Dual heteroatom (N and B/P/S)-doped graphene/CNT catalysts have also been investigated. Iron- or nickel-based catalysts on N-doped graphene/CNT are also emerging technologies in fuel cell research, although these metals dissolve in acidic solutions and are utilized for AWE. These metal- or platinum-free catalysts could reduce the cost of platinum catalysts. Interestingly, nickel phosphide in cluster III-4, which exhibits high catalytic activity for OER and is stable in acid, has not been studied in fuel cell research. $\mathrm{Ni}_{5} \mathrm{P}_{4}$ and $\mathrm{CoP}$ have recently been invented and are mainly utilized in water electrolysis. These compounds could become more stable, which would allow them to be utilized in fuel cells. This catalyst could be an example of reverse transfer from water electrolysis to fuel cell research.

It appears to be difficult to develop AWE from fuel cell technologies, because fuel cell research no longer focuses on AFC [18]. In AFC, carbonate accumulates on electrodes due to a reaction between cations and $\mathrm{CO}_{2}$ in air, which also limit cation mobility and decrease ion conductivity. Instead of AFC, SAFC has recently received attention in fuel cell research, which has been transferred as cluster I-G "Anion exchange polymer membrane electrolysis cell". The challenge of SAFC is in the chemical stability of the electrolyte membrane. SAFC studies have not developed a representative electrolyte, such as Nafion in cation exchange membrane studies. The electrolytes in SAFC involve the whole system, because humidification is required to maintain high ion conductivity, which requires heat recovery and humidity management (excessive humidity promotes water stack in the electrode and disrupts the diffusion of reactants and products). Therefore, as a standard electrolyte for SAFC has not yet been developed, intensive research of the whole system is not conducted. This means that investigation of the whole system in cluster I-G is not sufficient. When a suitably stable anion exchange membrane is developed, SAFC technologies can be transferred to water electrolysis, and system 
research can be conducted. In the application of SAFC technologies to water electrolysis, it is notable that a $\mathrm{KOH}$-doped electrolyte can be utilized because the electrolytes are not exposed to air. $\mathrm{KOH}$ cannot be employed in SAFC, because it reacts with $\mathrm{CO}_{2}$ in air and carbonate accumulates and disturbs the reaction and mass flow on the electrode. Electrolytes in SAFC are chemically unstable because a high $\mathrm{OH}^{-}$concentration is required for sufficient conductivity, and the base groups that can produce $\mathrm{OH}^{-}$and achieve the high concentration decompose at the operational temperature. Meanwhile, in $\mathrm{KOH}$-doped electrolytes, $\mathrm{KOH}$ plays a role in enhancing $\mathrm{OH}^{-}$conductivity and the priority of electrolytes can be stability. Although some studies have already tested $\mathrm{KOH}$-doped electrolytes and found that they are not stable enough [135], such research should be conducted for water electrolysis.

Nafion is typically used as an electrolyte membrane in PEME, and is sufficient for water electrolysis because the availability of water retains the membrane's proton conductivity, which decreases at a low relative humidity. Studies on electrolytes in PEFC aim to improve proton conductivity at a low relative humidity, which is unnecessary for water electrolysis because water electrolysis cell has a plenty of water originally [18]. However, hydrocarbon-based polymers contain hydrocarbons without the ecologically-harmful fluorine, and can be synthesized in a few steps, resulting in a relatively small cost if the polymer's structure is random, which differs from Nafion. Although hydrocarbon-based polymers with a random structure do not exhibit high proton conductivity at low humidity, they could be sufficient for water electrolysis below boiling point. Hydrocarbon-based electrolytes are not often used in water electrolysis, and could be transferred as affordable electrolytes. Furthermore, as examined in cluster II-D, steam electrolysis beyond boiling point has several advantages, but experiences low proton conductivity at low humidity because, at atmospheric pressure, steam is insufficient to humidify electrolytes beyond boiling point. Currently, phosphoric acid-doped PBI or PFSA is mainly utilized in cluster II-D. There are only 20 publications in cluster II-D, and these electrolytes could be replaced by recently-developed electrolytes in fuel cell research, such as inorganic-organic composites. Additionally, hydrocarbon-based block copolymers can be used as an alternative and retain proton conductivity at a low relative humidity, although synthesis of this electrolyte requires several steps, and it is relatively expensive.

As studied in cluster IV-D, the stability of the anode in SOEC is a challenge, which differs from SOFC. Clusters IV-C examine the materials transferred from fuel cell research; however, over long-term operation, the anode will degrade. Research of SOFC is almost mature [18], which means that SOFC researchers will need to find another topic related to their expertise, which could be SOEC.

MEC research has rapidly expanded in the recent past as well as MFC. Plenty of the technologies developed in MFC have not been applied to MEC. In MFC, direct electron transfer (DET) is of great interest [18]. A challenge in MFC is the overpotential caused by electron transfer from the biocatalysts to the electrodes. MFC has conventionally used redox molecules or polymers that can transfer electrons between the catalytic center and electrode, although this reduces the voltage from MFC. To avoid this, DET has been investigated to transfer electrons from enzymes in a microbiome to electrodes via a redox protein in their membrane. The electron transfer mechanisms of Geobacter and Shewanella have been investigated for DET in MFC. This has received extensive focus in MEC research, yet internal loss due to redox molecules or polymers could be decreased. MEC can avoid producing $\mathrm{O}_{2}$ in the anode; therefore, it can be operated under anaerobic conditions, which is suitable for anaerobic bacteria such as Geobacter and Shewanella. Therefore, MEC research can employ bacteria that have been abandoned in MFC due to their sensitivity to oxygen. The challenges surrounding the electrolyte and platinum in the cathode in MEC can be solved by the technologies used in PEFC. The electrolytes developed in PEFC research, and less-expensive catalysts such as N-doped graphene/CNT, could be used in MEC. As the pair technology of MFC, enzymatic biofuel (EBFC) has been developed in the fuel cell research area. EBFC only uses enzymes as biocatalysts, and does not require whole bacteria. It enhances the current density per unit volume of the device. However, it is difficult to regenerate biocatalysts, which differs from MFC. For water electrolysis, the current density per volume is a low priority, 
and EBFC technologies are rarely exported to MEC. If a very stable catalyst is developed in EBFC research, the catalyst can be examined in MEC.

\section{Conclusions}

We performed a comprehensive and objective analysis of all research water electrolysis areas following a computational method based on a citation network. The analysis shows that all research areas are receiving attention, especially that for MEC and catalysts for AWE and PEME. By comparing with the review of fuel cell research, we found that many technologies have not yet been transferred from fuel cell to water electrolysis research. The promising transferable technologies are heteroatom-doped graphene/CNT and nickel/cobalt phosphide for catalysts, hydrocarbon-based polymers, and inorganic-organic composites for electrolytes. Especially, some conditions for components are different between fuel cell and water electrolysis research, which can utilize several technologies that have been abandoned in fuel cell research, such as the use of a $\mathrm{KOH}$-doped anion exchange membrane and DET using anaerobic bacteria. These technologies should receive attention and could become future water electrolysis research trends.

Acknowledgments: Part of this research was financially supported by the following project: "Comprehensive scenario analysis for prospects and bottleneck of hydrogen energy in future energy system" (FY2016-FY2017) in the program of Advancement of Hydrogen Technologies and Utilization Project, New Energy and Industrial Technology Development Organization (NEDO).

Conflicts of Interest: The authors declare no conflict of interest. The founding sponsors had no role in the design of the study; in the collection, analyses, or interpretation of data; in the writing of the manuscript, and in the decision to publish the results.

\section{References}

1. Anvari, M.; Lohmann, G.; Wachter, M.; Milan, P.; Lorenz, E.; Heinemann, D.; Tabar, M.R.R.; Peinke, J. Short term fluctuations of wind and solar power systems. New J. Phys. 2016, 18, 063027. [CrossRef]

2. Hernandez, R.R.; Hoffacker, M.K.; Murphy-Mariscal, M.L.; Wu, G.C.; Allen, M.F. Solar energy development impacts on land cover change and protected areas. Proc. Natl. Acad. Sci. USA 2015, 112, 13579-13584. [CrossRef] [PubMed]

3. Hedegaard, K.; Meibom, P. Wind power impacts and electricity storage-A time scale perspective. Renew. Energy 2012, 37, 318-324. [CrossRef]

4. Zeng, K.; Zhang, D. Recent progress in alkaline water electrolysis for hydrogen production and applications. Prog. Energy Combust. Sci. 2010, 36, 307-326. [CrossRef]

5. Wang, M.; Wang, Z.; Gong, X.; Guo, Z. The intensification technologies to water electrolysis for hydrogen production-A review. Renew. Sustain. Energy Rev. 2014, 29, 573-588. [CrossRef]

6. Bi, L.; Boulfrad, S.; Traversa, E. Steam electrolysis by solid oxide electrolysis cells (SOECs) with proton-conducting oxides. Chem. Soc. Rev. 2014, 43, 8255-8270. [CrossRef] [PubMed]

7. Ho, J.C.; Saw, E.C.; Lu, L.Y.Y.; Liu, J.S. Technological barriers and research trends in fuel cell technologies: A citation network analysis. Technol. Forecast. Soc. Chang. 2014, 82, 66-79. [CrossRef]

8. Small, H. Tracking and predicting growth areas in science. Scientometrics 2006, 68, 595-610. [CrossRef]

9. Wan, L.; Wei, Y.M.; Brown, M.A. Global transition to low-carbon electricity: A bibliometric analysis. Appl. Energy 2017, 205, 57-68.

10. Suominen, A. Phases of growth in a green tech research network: A bibliometric evaluation of fuel cell technology from 1991 to 2010. Scientometrics 2014, 100, 51-72. [CrossRef]

11. Kajikawa, Y.; Ohno, J.; Takeda, Y.; Matsushima, K.; Komiyama, H. Creating an academic landscape of sustainability science: An analysis of the citation network. Sustain. Sci. 2007, 2, 221-231. [CrossRef]

12. Shibata, N.; Kajikawa, Y.; Takeda, Y.; Matsushima, K. Detecting emerging research fronts based on topological measures in citation networks of scientific publications. Technovation 2008, 28, 758-775. [CrossRef]

13. Kajikawa, Y.; Yoshikawa, J.; Takeda, Y.; Matsushima, K. Tracking emerging technologies in energy research: Towardaroadmap for sustainableenergy. Technol. Forecast. Soc. Chang. 2008, 75, 771-782. [CrossRef] 
14. Ogawa, T.; Iyoki, K.; Fukushima, T.; Kajikawa, Y. Landscape of Research Areas for Zeolites and Metal-Organic Frameworks Using Computational Classification Based on Citation Networks. Materials 2017, 10, 1428. [CrossRef] [PubMed]

15. Shibata, N.; Kajikawa, Y.; Sakata, I. Extracting the commercialization gap between science and technology case study of a solar cell. Technol. Forecast. Soc. Chang. 2010, 77, 1147-1155. [CrossRef]

16. Ogawa, T.; Kajikawa, Y. Assessing the industrial opportunity of academic research with patent relatedness: A case study on polymer electrolyte fuel cells. Technol. Forecast. Soc. Chang. 2015, 90, 469-475. [CrossRef]

17. Ogawa, T.; Kajikawa, Y. Generating novel research ideas using computational intelligence: A case study involving fuel cells and ammonia synthesis. Technol. Forecast. Soc. Chang. 2017, 120, 41-47. [CrossRef]

18. Ogawa, T.; Takeuchi, M.; Kajikawa, Y. Comprehensive analysis of trends and emerging technologies in all types of fuel cells based on a computational method. Sustainability 2018, 10, 458. [CrossRef]

19. Shibata, N.; Kajikawa, Y.; Takeda, Y.; Matsushima, K. Comparative study on methods of detecting research fronts using different types of citation. J. Am. Soc. Inf. Sci. Technol. 2009, 60, 571-580. [CrossRef]

20. Newman, M. Fast algorithm for detecting community structure in networks. Phys. Rev. E 2004, 69, 066133. [CrossRef] [PubMed]

21. Bass, F.M. A new product growth for model consumer durables. Manag. Sci. 1969, 15, 215-227. [CrossRef]

22. Bass, F.M. Comments on "a new product growth for model consumer durables the bass model". Manag. Sci. 2004, 50, 1833-1840. [CrossRef]

23. Adai, A.T.; Date, S.V.; Wieland, S.; Marcotte, E.M. Lgl: Creating a map of protein function with an algorithm for visualizing very large biological networks. J. Mol. Biol. 2004, 340, 179-190. [CrossRef] [PubMed]

24. Carmo, M.; Fritz, D.L.; Merge, J.; Stolten, D. A comprehensive review on PEM water electrolysis. Int. J. Hydrogen Energy 2013, 38, 4901-4934. [CrossRef]

25. Dönitz, W.; Erdle, E. High-temperature electrolysis of water vapor-Status of development and perspectives for application. Int. J. Hydrogen Energy 1985, 10, 291-295. [CrossRef]

26. Laguna-Bercero, M.A. Recent advances in high temperature electrolysis using solid oxide fuel cells: A review. J. Power Sources 2012, 203, 4-16. [CrossRef]

27. Ebbesen, S.D.; Jensen, S.H.; Hauch, A.; Mogensen, M.B. High temperature electrolysis in alkaline cells, solid proton conducting cells, and solid oxide cells. Chem. Rev. 2014, 114, 10697-10734. [CrossRef] [PubMed]

28. Liu, H.; Grot, S.; Logan, B.E. Electrochemically assisted microbial production of hydrogen from acetate. Environ. Sci. Technol. 2005, 39, 4317-4320. [CrossRef] [PubMed]

29. Miyake, J.; Miyake, M.; Asada, Y. Biotechnological hydrogen production: Research for efficient light energy conversion. J. Biotechnol. 1999, 70, 89-101. [CrossRef]

30. Logan, B.E.; Hamelers, B.; Rozendal, R.; Schröder, U.; Keller, J.; Freguia, S.; Aelterman, P.; Verstraete, W.; Rabaey, K. Microbial fuel cells: Methodology and technology. Environ. Sci. Technol. 2006, 40, 5181-5192. [CrossRef] [PubMed]

31. Safizadeh, F.; Ghali, E.; Houlachi, G. Electrocatalysis developments for hydrogen evolution reaction in alkaline solutions-A review. Int. J. Hydrogen Energy 2015, 40, 256-274. [CrossRef]

32. Subbaraman, R.; Tripkovic, D.; Strmcnik, D.; Chang, K.-C.; Uchimura, M.; Paulikas, A.P.; Stamenkovic, V.; Markovic, N.M. Enhancing hydrogen evolution activity in water splitting by tailoring $\mathrm{Li}^{+}-\mathrm{Ni}(\mathrm{OH})_{2}-\mathrm{Pt}$ interfaces. Science 2011, 334, 1256-1260. [CrossRef] [PubMed]

33. Ahn, S.H.; Hwang, S.J.; Yoo, S.J.; Choi, I.; Kim, H.-J.; Jang, J.H.; Nam, S.W.; Lim, T.-H.; Lim, T.; Kim, S.-K.; et al. Electrodeposited Ni dendrites with high activity and durability for hydrogen evolution reaction in alkaline water electrolysis. J. Mater. Chem. 2012, 22, 15153-15159. [CrossRef]

34. Burke, L.D.; Naser, N.S. Metastability and electrocatalytic activity of ruthenium dioxide cathodes used in water electrolysis cells. J. Appl. Electrochem. 2005, 35, 931-938. [CrossRef]

35. Holmin, S.; Näslund, L.-Å.; Ingason, Á.S.; Rosen, J.; Zimmerman, E. Corrosion of ruthenium dioxide based cathodes in alkaline medium caused by reverse currents. Electrochim. Acta 2014, 146, 30-36. [CrossRef]

36. Näslund, L.-Å.; Ingason, Á.S.; Holmin, S.; Rosen, J. Formation of $\mathrm{RuO}(\mathrm{OH})_{2}$ on $\mathrm{RuO}_{2}$-based electrodes for hydrogen production. J. Phys. Chem. C 2014, 118, 15315-15323. [CrossRef]

37. Matsushima, H.; Nishida, T.; Konishi, Y.; Fukunaka, Y.; Ito, Y.; Kuribayashi, K. Water electrolysis under microgravity: Part 1. Experimental technique. Electrochim. Acta 2003, 48, 4119-4125. [CrossRef]

38. Matsushima, H.; Fukunaka, Y.; Kuribayashi, K. Water electrolysis under microgravity: Part II. Description of gas bubble evolution phenomena. Electrochim. Acta 2006, 51, 4190-4198. [CrossRef] 
39. Xiao, L.; Zhang, S.; Pan, J.; Yang, C.; He, M.; Zhuang, L.; Lu, J. First implementation of alkaline polymer electrolyte water electrolysis working only with pure water. Energy Environ. Sci. 2012, 5, 7869-7871. [CrossRef]

40. Leng, Y.; Chen, G.; Mendoza, A.J.; Tighe, T.B.; Hickner, M.A.; Wang, C.-Y. Solid-state water electrolysis with an alkaline membrane. J. Am. Chem. Soc. 2012, 134, 9054-9057. [CrossRef] [PubMed]

41. Cheng, J.; Zhang, H.; Chen, G.; Zhang, Y. Study of $\mathrm{Ir}_{\mathrm{x}} \mathrm{Ru}_{1-\mathrm{x}} \mathrm{O}_{2}$ oxides as anodic electrocatalysts for solid polymer electrolyte water electrolysis. Electrochim. Acta 2009, 54, 6250-6256. [CrossRef]

42. Marshall, A.; Børresen, B.; Hagen, G.; Tsypkin, M.; Tunold, R. Electrochemical characterisation of $\operatorname{Ir}_{\mathrm{x}} \mathrm{Sn}_{1-\mathrm{x}} \mathrm{O}_{2}$ powders as oxygen evolution electrocatalysts. Electrochim. Acta 2006, 51, 3161-3167. [CrossRef]

43. Grigoriev, S.A.; Millet, P.; Dzhus, K.A.; Middleton, H.; Saetre, T.O.; Fateev, V.N. Design and characterization of bi-functional electrocatalytic layers for application in pem unitized regenerative fuel cells. Int. J. Hydrogen Energy 2010, 35, 5070-5076. [CrossRef]

44. Pettersson, J.; Ramsey, B.; Harrison, D. A review of the latest developments in electrodes for unitised regenerative polymer electrolyte fuel cells. J. Power Sources 2006, 157, 28-34. [CrossRef]

45. Gabbasa, M.; Sopian, K.; Fudholi, A.; Asim, N. A review of unitized regenerative fuel cell stack: Material, design and research achievements. Int. J. Hydrogen Energy 2014, 39, 17765-17778. [CrossRef]

46. Nikiforov, A.V.; Petrushina, I.M.; Christensen, E.; Tomás-García, A.L.; Bjerrum, N.J. Corrosion behaviour of construction materials for high temperature steam electrolysers. Int. J. Hydrogen Energy 2011, 36, 111-119. [CrossRef]

47. Aili, D.; Hansen, M.K.; Pan, C.; Li, Q.; Christensen, E.; Jensen, J.O.; Bjerrum, N.J. Phosphoric acid doped membranes based on Nafion ${ }^{\circledR}$, PBI and their blends-Membrane preparation, characterization and steam electrolysis testing. Int. J. Hydrogen Energy 2011, 36, 6985-6993. [CrossRef]

48. Hansen, M.K.; Aili, D.; Christensen, E.; Pan, C.; Eriksen, S.; Jensen, J.O.; von Barner, J.H.; Li, Q.; Bjerrum, N.J. PEM steam electrolysis at $130^{\circ} \mathrm{C}$ using a phosphoric acid doped short side chain pfsa membrane. Int. J. Hydrogen Energy 2012, 37, 10992-11000. [CrossRef]

49. Take, T.; Tsurutani, K.; Umeda, M. Hydrogen production by methanol-water solution electrolysis. J. Power Sources 2007, 164, 9-16. [CrossRef]

50. Lamy, C.; Jaubert, T.; Baranton, S.; Coutanceau, C. Clean hydrogen generation through the electrocatalytic oxidation of ethanol in a proton exchange membrane electrolysis cell (PEMEc): Effect of the nature and structure of the catalytic anode. J. Power Sources 2014, 245, 927-936. [CrossRef]

51. Marshall, A.T.; Haverkamp, R.G. Production of hydrogen by the electrochemical reforming of glycerol-water solutions in a PEM electrolysis cell. Int. J. Hydrogen Energy 2008, 33, 4649-4654. [CrossRef]

52. Jiao, F.; Frei, H. Nanostructured cobalt oxide clusters in mesoporous silica as efficient oxygen-evolving catalysts. Angew. Chem. Int. Ed. 2009, 48, 1841-1844. [CrossRef] [PubMed]

53. Trotochaud, L.; Ranney, J.K.; Williams, K.N.; Boettcher, S.W. Solution-cast metal oxide thin film electrocatalysts for oxygen evolution. J. Am. Chem. Soc. 2012, 134, 17253-17261. [CrossRef] [PubMed]

54. Meng, Y.; Song, W.; Huang, H.; Ren, Z.; Chen, S.-Y.; Suib, S.L. Structure-property relationship of bifunctional $\mathrm{MnO}_{2}$ nanostructures: Highly efficient, ultra-stable electrochemical water oxidation and oxygen reduction reaction catalysts identified in alkaline media. J. Am. Chem. Soc. 2014, 136, 11452-11464. [CrossRef] [PubMed]

55. Liu, X.; Jia, H.; Sun, Z.; Chen, H.; Xu, P.; Du, P. Nanostructured copper oxide electrodeposited from copper(II) complexes as an active catalyst for electrocatalytic oxygen evolution reaction. Electrochem. Commun. 2014, 46, 1-4. [CrossRef]

56. McCrory, C.C.L.; Jung, S.; Peters, J.C.; Jaramillo, T.F. Benchmarking heterogeneous electrocatalysts for the oxygen evolution reaction. J. Am. Chem. Soc. 2013, 135, 16977-16987. [CrossRef] [PubMed]

57. Singh, R.N.; Singh, J.P.; Lal, B.; Thomas, M.J.K.; Bera, S. New $\mathrm{NiFe}_{2-x} \mathrm{Cr}_{\mathrm{x}} \mathrm{O}_{4}$ spinel films for $\mathrm{O}_{2}$ evolution in alkaline solutions. Electrochim. Acta 2006, 51, 5515-5523. [CrossRef]

58. Srirapu, V.K.V.P.; Sharma, C.S.; Awasthi, R.; Singh, R.N.; Sinha, A.S.K. Copper-iron-molybdenum mixed oxides as efficient oxygen evolution electrocatalysts. Phys. Chem. Chem. Phys. 2014, 16, 7385-7393. [CrossRef] [PubMed]

59. Kumar, M.; Awasthi, R.; Pramanick, A.K.; Singh, R.N. New ternary mixed oxides of Fe, Ni and Mo for enhanced oxygen evolution. Int. J. Hydrogen Energy 2011, 36, 12698-12705. [CrossRef]

60. Singh, R.N.; Lal, B. High surface area lanthanum cobaltate and its A and B sites substituted derivatives for electrocatalysis of $\mathrm{O}_{2}$ evolution in alkaline solution. Int. J. Hydrogen Energy 2002, 27, 45-55. [CrossRef] 
61. Singh, R.N.; Tiwari, S.K.; Singh, S.P.; Singh, N.K.; Poillerat, G.; Chartier, P. Synthesis of (La, Sr)CoO 3 perovskite films via a sol-gel route and their physicochemical and electrochemical surface characterization for anode application in alkaline water electrolysis. J. Chem. Soc. Faraday Trans. 1996, 92, 2593-2597. [CrossRef]

62. Liu, Q.; Tian, J.; Cui, W.; Jiang, P.; Cheng, N.; Asiri, A.M.; Sun, X. Carbon nanotubes decorated with CoP nanocrystals: A highly active non-noble-metal nanohybrid electrocatalyst for hydrogen evolution. Angew. Chem. Int. Ed. 2014, 126, 6828-6832. [CrossRef]

63. Voiry, D.; Yamaguchi, H.; Li, J.; Silva, R.; Alves, D.C.B.; Fujita, T.; Chen, M.; Asefa, T.; Shenoy, V.B.; Eda, G.; et al. Enhanced catalytic activity in strained chemically exfoliated $\mathrm{WS}_{2}$ nanosheets for hydrogen evolution. Nat. Mater. 2013, 12, 850-855. [CrossRef] [PubMed]

64. Popczun, E.J.; McKone, J.R.; Read, C.G.; Biacchi, A.J.; Wiltrout, A.M.; Lewis, N.S.; Schaak, R.E. Nanostructured nickel phosphide as an electrocatalyst for the hydrogen evolution reaction. J. Am. Chem. Soc. 2013, 135, 9267-9270. [CrossRef] [PubMed]

65. Kong, D.; Wang, H.; Lu, Z.; Cui, Y. CoSe 2 nanoparticles grown on carbon fiber paper: An efficient and stable electrocatalyst for hydrogen evolution reaction. J. Am. Chem. Soc. 2014, 136, 4897-4900. [CrossRef] [PubMed]

66. Merki, D.; Fierro, S.; Vrubel, H.; Hu, X. Amorphous molybdenum sulfide films as catalysts for electrochemical hydrogen production in water. Chem. Sci. 2011, 2, 1262-1267. [CrossRef]

67. Chen, W.F.; Wang, C.H.; Sasaki, K.; Marinkovic, N.; Xu, W.; Muckerman, J.T.; Zhu, Y.; Adzic, R.R. Highly active and durable nanostructured molybdenum carbide electrocatalysts for hydrogen production. Energy Environ. Sci. 2013, 6, 943-951. [CrossRef]

68. Sun, Y.; Gao, S.; Lei, F.; Liu, J.; Liang, L.; Xie, Y. Atomically-thin non-layered cobalt oxide porous sheets for highly efficient oxygen-evolving electrocatalysts. Chem. Sci. 2014, 5, 3976-3982. [CrossRef]

69. Man, I.C.; Su, H.-Y.; Calle-Vallejo, F.; Hansen, H.A.; Martínez, J.I.; Inoglu, N.G.; Kitchin, J.; Jaramillo, T.F.; Nørskov, J.K.; Rossmeisl, J. Universality in oxygen evolution electrocatalysis on oxide surfaces. ChemCatChem 2011, 3, 1159-1165. [CrossRef]

70. Lee, Y.; Suntivich, J.; May, K.J.; Perry, E.E.; Shao-Horn, Y. Synthesis and activities of rutile $\mathrm{IrO}_{2}$ and $\mathrm{RuO}_{2}$ nanoparticles for oxygen evolution in acid and alkaline solutions. J. Phys. Chem. Lett. 2012, 3, 399-404. [CrossRef] [PubMed]

71. Liang, F.; Yu, Y.; Zhou, W.; Xu, X.; Zhu, Z. Highly defective $\mathrm{CeO}_{2}$ as a promoter for efficient and stable water oxidation. J. Mater. Chem. A 2015, 3, 634-640. [CrossRef]

72. Kötz, R.; Stucki, S. Stabilization of $\mathrm{RuO}_{2}$ by $\mathrm{IrO}_{2}$ for anodic oxygen evolution in acid media. Electrochim. Acta 1986, 31, 1311-1316. [CrossRef]

73. Louie, M.W.; Bell, A.T. An investigation of thin-film Ni-Fe oxide catalysts for the electrochemical evolution of oxygen. J. Am. Chem. Soc. 2013, 135, 12329-12337. [CrossRef] [PubMed]

74. Gong, M.; Dai, H. A mini review of NiFe-based materials as highly active oxygen evolution reaction electrocatalysts. Nano Res. 2015, 8, 23-39. [CrossRef]

75. Stern, L.-A.; Feng, L.; Song, F.; Hu, X. Ni ${ }_{2} \mathrm{P}$ as a janus catalyst for water splitting: The oxygen evolution activity of $\mathrm{Ni}_{2} \mathrm{P}$ nanoparticles. Energy Environ. Sci. 2015, 8, 2347-2351. [CrossRef]

76. Laursen, A.B.; Patraju, K.R.; Whitaker, M.J.; Retuerto, M.; Sarkar, T.; Yao, N.; Ramanujachary, K.V.; Greenblatt, M.; Dismukes, G.C. Nanocrystalline ni5p4: A hydrogen evolution electrocatalyst of exceptional efficiency in both alkaline and acidic media. Energy Environ. Sci. 2015, 8, 1027-1034. [CrossRef]

77. Ledendecker, M.; Krick Calderón, S.; Papp, C.; Steinrück, H.-P.; Antonietti, M.; Shalom, M. The synthesis of nanostructured $\mathrm{Ni}_{5} \mathrm{P}_{4}$ films and their use as a non-noble bifunctional electrocatalyst for full water splitting. Angew. Chem. Int. Ed. 2015, 54, 12361-12365. [CrossRef] [PubMed]

78. El-Deab, M.S.; Awad, M.I.; Mohammad, A.M.; Ohsaka, T. Enhanced water electrolysis: Electrocatalytic generation of oxygen gas at manganese oxide nanorods modified electrodes. Electrochem. Commun. 2007, 9, 2082-2087. [CrossRef]

79. Mette, K.; Bergmann, A.; Tessonnier, J.-P.; Hävecker, M.; Yao, L.; Ressler, T.; Schlögl, R.; Strasser, P.; Behrens, M. Nanostructured manganese oxide supported on carbon nanotubes for electrocatalytic water splitting. ChemCatChem 2012, 4, 851-862. [CrossRef]

80. Faber, M.S.; Lukowski, M.A.; Ding, Q.; Kaiser, N.S.; Jin, S. Earth-abundant metal pyrites $\left(\mathrm{FeS}_{2}, \mathrm{CoS}_{2}, \mathrm{NiS}_{2}\right.$, and their alloys) for highly efficient hydrogen evolution and polysulfide reduction electrocatalysis. J. Phys. Chem. C 2014, 118, 21347-21356. [CrossRef] [PubMed] 
81. Wang, K.; Xi, D.; Zhou, C.; Shi, Z.; Xia, H.; Liu, G.; Qiao, G. CoSe 2 necklace-like nanowires supported by carbon fiber paper: A 3d integrated electrode for the hydrogen evolution reaction. J. Mater. Chem. A 2015, 3, 9415-9420. [CrossRef]

82. Li, G.; Zhang, D.; Qiao, Q.; Yu, Y.; Peterson, D.; Zafar, A.; Kumar, R.; Curtarolo, S.; Hunte, F.; Shannon, S.; et al. All the catalytic active sites of $\mathrm{MoS}_{2}$ for hydrogen evolution. J. Am. Chem. Soc. 2016, 138, 16632-16638. [CrossRef] [PubMed]

83. Jaramillo, T.F.; Jørgensen, K.P.; Bonde, J.; Nielsen, J.H.; Horch, S.; Chorkendorff, I. Identification of active edge sites for electrochemical $\mathrm{H}_{2}$ evolution from $\mathrm{MoS}_{2}$ nanocatalysts. Science 2007, 317, 100-102. [CrossRef] [PubMed]

84. Wang, H.; Tsai, C.; Kong, D.; Chan, K.; Abild-Pedersen, F.; Nørskov, J.K.; Cui, Y. Transition-metal doped edge sites in vertically aligned $\mathrm{MoS}_{2}$ catalysts for enhanced hydrogen evolution. Nano Res. 2015, 8, 566-575. [CrossRef]

85. Harnisch, F.; Sievers, G.; Schröder, U. Tungsten carbide as electrocatalyst for the hydrogen evolution reaction in pH neutral electrolyte solutions. Appl. Catal. B 2009, 89, 455-458. [CrossRef]

86. Esposito, D.V.; Hunt, S.T.; Kimmel, Y.C.; Chen, J.G. A new class of electrocatalysts for hydrogen production from water electrolysis: Metal monolayers supported on low-cost transition metal carbides. J. Am. Chem. Soc. 2012, 134, 3025-3033. [CrossRef] [PubMed]

87. Esposito, D.V.; Chen, J.G. Monolayer platinum supported on tungsten carbides as low-cost electrocatalysts: Opportunities and limitations. Energy Environ. Sci. 2011, 4, 3900-3912. [CrossRef]

88. Zhang, T.; Wang, C.; Liu, S.; Wang, J.-L.; Lin, W. A biomimetic copper water oxidation catalyst with low overpotential. J. Am. Chem. Soc. 2014, 136, 273-281. [CrossRef] [PubMed]

89. Lu, C.; Du, J.; Su, X.-J.; Zhang, M.-T.; Xu, X.; Meyer, T.J.; Chen, Z. Cu(II) aliphatic diamine complexes for both heterogeneous and homogeneous water oxidation catalysis in basic and neutral solutions. ACS Catal. 2016, 6, 77-83. [CrossRef]

90. Udagawa, J.; Aguiar, P.; Brandon, N.P. Hydrogen production through steam electrolysis: Model-based steady state performance of a cathode-supported intermediate temperature solid oxide electrolysis cell. J. Power Sources 2007, 166, 127-136. [CrossRef]

91. Ni, M.; Leung, M.K.H.; Leung, D.Y.C. Mathematical modeling of the coupled transport and electrochemical reactions in solid oxide steam electrolyzer for hydrogen production. Electrochim. Acta 2007, 52, 6707-6718. [CrossRef]

92. Graves, C.; Ebbesen, S.D.; Mogensen, M.; Lackner, K.S. Sustainable hydrocarbon fuels by recycling $\mathrm{CO}_{2}$ and $\mathrm{H}_{2} \mathrm{O}$ with renewable or nuclear energy. Renew. Sustain. Energy Rev. 2011, 15, 1-23. [CrossRef]

93. Ebbesen, S.D.; Mogensen, M. Electrolysis of carbon dioxide in solid oxide electrolysis cells. J. Power Sources 2009, 193, 349-358. [CrossRef]

94. Yildiz, B.; Kazimi, M. Efficiency of hydrogen production systems using alternative nuclear energy technologies. Int. J. Hydrogen Energy 2006, 31, 77-92. [CrossRef]

95. O’Brien, J.E.; Stoots, C.M.; Herring, J.S.; Hartvigsen, J.J. Performance of planar high-temperature electrolysis stacks for hydrogen production from nuclear energy. Nucl. Technol. 2007, 158, 118-131. [CrossRef]

96. O'Brien, J.E.; Stoots, C.M.; Herring, J.S.; Hartvigsen, J. Hydrogen production performance of a 10-cell planar solid-oxide electrolysis stack. J. Fuel Cell Sci. Technol. 2005, 3, 213-219. [CrossRef]

97. Yang, X.; Irvine, J.T.S. ( $\left.\mathrm{La}_{0.75} \mathrm{Sr}_{0.25}\right)_{0.95} \mathrm{Mn}_{0.5} \mathrm{Cr}_{0.5} \mathrm{O}_{3}$ as the cathode of solid oxide electrolysis cells for high temperature hydrogen production from steam. J. Mater. Chem. 2008, 18, 2349-2354. [CrossRef]

98. Jin, C.; Yang, C.; Zhao, F.; Cui, D.; Chen, F. $\mathrm{La}_{0.75} \mathrm{Sr}_{0.25} \mathrm{Cr}_{0.5} \mathrm{Mn}_{0.5} \mathrm{O}_{3}$ as hydrogen electrode for solid oxide electrolysis cells. Int. J. Hydrogen Energy 2011, 36, 3340-3346. [CrossRef]

99. Iwahara, H.; Asakura, Y.; Katahira, K.; Tanaka, M. Prospect of hydrogen technology using proton-conducting ceramics. Solid State Ion. 2004, 168, 299-310. [CrossRef]

100. Ishihara, T.; Jirathiwathanakul, N.; Zhong, H. Intermediate temperature solid oxide electrolysis cell using $\mathrm{LaGaO}_{3}$ based perovskite electrolyte. Energy Environ. Sci. 2010, 3, 665-672. [CrossRef]

101. Ishihara, T.; Kanno, T. Steam electrolysis using $\mathrm{LaGaO}_{3}$ based perovskite electrolyte for recovery of unused heat energy. ISIJ Int. 2010, 50, 1291-1295. [CrossRef]

102. Virkar, A.V. Mechanism of oxygen electrode delamination in solid oxide electrolyzer cells. Int. J. Hydrogen Energy 2010, 35, 9527-9543. [CrossRef] 
103. Chen, K.; Jiang, S.P. Failure mechanism of ( $\mathrm{La}, \mathrm{Sr}) \mathrm{MnO}_{3}$ oxygen electrodes of solid oxide electrolysis cells. Int. J. Hydrogen Energy 2011, 36, 10541-10549. [CrossRef]

104. Croese, E.; Pereira, M.A.; Euverink, G.-J.W.; Stams, A.J.M.; Geelhoed, J.S. Analysis of the microbial community of the biocathode of a hydrogen-producing microbial electrolysis cell. Appl. Microbiol. Biotechnol. 2011, 92, 1083-1093. [CrossRef] [PubMed]

105. Jeremiasse, A.W.; Hamelers, H.V.M.; Buisman, C.J.N. Microbial electrolysis cell with a microbial biocathode. Bioelectrochemistry 2010, 78, 39-43. [CrossRef] [PubMed]

106. Jeremiasse, A.W.; Hamelers, H.V.M.; Saakes, M.; Buisman, C.J.N. Ni foam cathode enables high volumetric $\mathrm{H}_{2}$ production in a microbial electrolysis cell. Int. J. Hydrogen Energy 2010, 35, 12716-12723. [CrossRef]

107. Selembo, P.A.; Merrill, M.D.; Logan, B.E. The use of stainless steel and nickel alloys as low-cost cathodes in microbial electrolysis cells. J. Power Sources 2009, 190, 271-278. [CrossRef]

108. Cheng, S.; Xing, D.; Call, D.F.; Logan, B.E. Direct biological conversion of electrical current into methane by electromethanogenesis. Environ. Sci. Technol. 2009, 43, 3953-3958. [CrossRef] [PubMed]

109. Kadier, A.; Kalil, M.S.; Abdeshahian, P.; Chandrasekhar, K.; Mohamed, A.; Azman, N.F.; Logroño, W.; Simayi, Y.; Hamid, A.A. Recent advances and emerging challenges in microbial electrolysis cells (MECs) for microbial production of hydrogen and value-added chemicals. Renew. Sustain. Energy Rev. 2016, 61, 501-525. [CrossRef]

110. Zhen, G.; Kobayashi, T.; Lu, X.; Xu, K. Understanding methane bioelectrosynthesis from carbon dioxide in a two-chamber microbial electrolysis cells (MECs) containing a carbon biocathode. Bioresour. Technol. 2015, 186, 141-148. [CrossRef] [PubMed]

111. Hu, H.; Fan, Y.; Liu, H. Hydrogen production using single-chamber membrane-free microbial electrolysis cells. Water Res. 2008, 42, 4172-4178. [CrossRef] [PubMed]

112. Tartakovsky, B.; Manuel, M.F.; Wang, H.; Guiot, S.R. High rate membrane-less microbial electrolysis cell for continuous hydrogen production. Int. J. Hydrogen Energy 2009, 34, 672-677. [CrossRef]

113. Rozendal, R.A.; Sleutels, T.H.J.A.; Hamelers, H.V.M.; Buisman, C.J.N. Effect of the type of ion exchange membrane on performance, ion transport, and $\mathrm{pH}$ in biocatalyzed electrolysis of wastewater. Water Sci. Technol. 2008, 57, 1757-1762. [CrossRef] [PubMed]

114. Sleutels, T.H.J.A.; Hamelers, H.V.M.; Rozendal, R.A.; Buisman, C.J.N. Ion transport resistance in microbial electrolysis cells with anion and cation exchange membranes. Int. J. Hydrogen Energy 2009, 34, 3612-3620. [CrossRef]

115. Junghare, M.; Subudhi, S.; Lal, B. Improvement of hydrogen production under decreased partial pressure by newly isolated alkaline tolerant anaerobe, clostridium butyricum TM-9A: Optimization of process parameters. Int. J. Hydrogen Energy 2012, 37, 3160-3168. [CrossRef]

116. Ust'ak, S.; Havrland, B.; Muñoz, J.O.J.; Fernández, E.C.; Lachman, J. Experimental verification of various methods for biological hydrogen production. Int. J. Hydrogen Energy 2007, 32, 1736-1741. [CrossRef]

117. Manish, S.; Banerjee, R. Comparison of biohydrogen production processes. Int. J. Hydrogen Energy 2008, 33, 279-286. [CrossRef]

118. Lu, L.; Ren, N.; Xing, D.; Logan, B.E. Hydrogen production with effluent from an ethanol- $\mathrm{H}_{2}$-coproducing fermentation reactor using a single-chamber microbial electrolysis cell. Biosens. Bioelectron. 2009, 24, 3055-3060. [CrossRef] [PubMed]

119. Liu, W.; Huang, S.; Zhou, A.; Zhou, G.; Ren, N.; Wang, A.; Zhuang, G. Hydrogen generation in microbial electrolysis cell feeding with fermentation liquid of waste activated sludge. Int. J. Hydrogen Energy 2012, 37, 13859-13864. [CrossRef]

120. Ajayi, F.F.; Kim, K.-Y.; Chae, K.-J.; Choi, M.-J.; Kim, S.-Y.; Chang, I.-S.; Kim, I.S. Study of hydrogen production in light assisted microbial electrolysis cell operated with dye sensitized solar cell. Int. J. Hydrogen Energy 2009, 34, 9297-9304. [CrossRef]

121. Chae, K.-J.; Choi, M.-J.; Kim, K.-Y.; Ajayi, F.F.; Chang, I.-S.; Kim, I.S. A solar-powered microbial electrolysis cell with a platinum catalyst-free cathode to produce hydrogen. Environ. Sci. Technol. 2009, 43, 9525-9530. [CrossRef] [PubMed]

122. Wu, D.; Pan, Y.; Huang, L.; Zhou, P.; Quan, X.; Chen, H. Complete separation of Cu(II), Co(II) and $\mathrm{Li}(\mathrm{I})$ using self-driven MFCs-MECs with stainless steel mesh cathodes under continuous flow conditions. Sep. Purif. Technol. 2015, 147, 114-124. [CrossRef] 
123. Mehanna, M.; Saito, T.; Yan, J.; Hickner, M.; Cao, X.; Huang, X.; Logan, B.E. Using microbial desalination cells to reduce water salinity prior to reverse osmosis. Energy Environ. Sci. 2010, 3, 1114-1120. [CrossRef]

124. Sevda, S.; Yuan, H.; He, Z.; Abu-Reesh, I.M. Microbial desalination cells as a versatile technology: Functions, optimization and prospective. Desalination 2015, 371, 9-17. [CrossRef]

125. Ipsakis, D.; Voutetakis, S.; Seferlis, P.; Stergiopoulos, F.; Elmasides, C. Power management strategies for a stand-alone power system using renewable energy sources and hydrogen storage. Int. J. Hydrogen Energy 2009, 34, 7081-7095. [CrossRef]

126. Vosen, S.R.; Keller, J.O. Hybrid energy storage systems for stand-alone electric power systems: Optimization of system performance and cost through control strategies. Int. J. Hydrogen Energy 1999, 24, 1139-1156. [CrossRef]

127. Zhou, T.; Francois, B. Modeling and control design of hydrogen production process for an active hydrogen/wind hybrid power system. Int. J. Hydrogen Energy 2009, 34, 21-30. [CrossRef]

128. Beccali, M.; Brunone, S.; Finocchiaro, P.; Galletto, J.M. Method for size optimisation of large wind-hydrogen systems with high penetration on power grids. Appl. Energy 2013, 102, 534-544. [CrossRef]

129. Olateju, B.; Kumar, A.; Secanell, M. A techno-economic assessment of large scale wind-hydrogen production with energy storage in western canada. Int. J. Hydrogen Energy 2016, 41, 8755-8776. [CrossRef]

130. Clarke, R.E.; Giddey, S.; Ciacchi, F.T.; Badwal, S.P.S.; Paul, B.; Andrews, J. Direct coupling of an electrolyser to a solar PV system for generating hydrogen. Int. J. Hydrogen Energy 2009, 34, 2531-2542. [CrossRef]

131. García-Valverde, R.; Espinosa, N.; Urbina, A. Optimized method for photovoltaic-water electrolyser direct coupling. Int. J. Hydrogen Energy 2011, 36, 10574-10586. [CrossRef]

132. Tolga Balta, M.; Dincer, I.; Hepbasli, A. Thermodynamic assessment of geothermal energy use in hydrogen production. Int. J. Hydrogen Energy 2009, 34, 2925-2939. [CrossRef]

133. Joshi, A.S.; Dincer, I.; Reddy, B.V. Exergetic assessment of solar hydrogen production methods. Int. J. Hydrogen Energy 2010, 35, 4901-4908. [CrossRef]

134. Balta, M.T.; Dincer, I.; Hepbasli, A. Potential methods for geothermal-based hydrogen production. Int. J. Hydrogen Energy 2010, 35, 4949-4961. [CrossRef]

135. Aili, D.; Hansen, M.K.; Renzaho, R.F.; Li, Q.; Christensen, E.; Jensen, J.O.; Bjerrum, N.J. Heterogeneous anion conducting membranes based on linear and crosslinked $\mathrm{KOH}$ doped polybenzimidazole for alkaline water electrolysis. J. Membr. Sci. 2013, 447, 424-432. [CrossRef] 